\title{
PENERAPAN GUGATAN SEDERHANA (SMALL CLAIM COURT) DALAM PENYELESAIAN PERKARA WANPRESTASI DI PENGADILAN NEGERI SELONG
}

\author{
Erna Purnawati \\ Fakultas Hukum Universitas Gunung Rinjani \\ e-mail : ernapurnawati293@gmail.com
}

\section{Info Artikel}

Sejarah Artikel :

Diterima Juni 2020

Disetujui Oktober 2020

Publikasi November 2020

\section{Keyword:}

Application Simple Lawsuit, breach of contract, Selong District Court

\section{Alustract}

This study aims to determine how the application of a simple claim court in the settlement of default cases at Selong District Court, and to find out what aret the obstacles to a small claim court in settling default cases at Selong District Court. The benefits of this research are expected to provide input in the development of legal science, especially in the field of civil law related of the settlement of simple lawsuits, especially the classification of cases breach of contract. The method used in this research is empirically legal research. The result showed that the implementation of Perma Number 2 of 2015 and Perma umber 4 of 2019 concerning Procedures for solving simple lawsuits at Selong District Court was carried out effectively with constraints that were more due to the weakness of the Perma itself internally.

\section{Ahstrak}

Penelitian ini bertujuan untuk mengetahui bagaimana penerapan gugatan sederhana (small claim court) dalam penyelesaian perkara wanprestasi di Pengadilan Negeri Selong, dan untuk mengetahui apa saja kendala gugatan sederhana (small claim court) dalam penyelesaian perkara wanprestasi di Pengadilan Negeri Selong. Manfaat penelitian ini diharapkan dapat memberikan masukan dalam pengembangan ilmu hukum, khususnya dalam bidang hukum perdata yang berkaitan dengan penyelesaian perkara gugatan sederhana khususnya klasifiasi perkara wanprestasi. Metode yang digunakan dalam peneitian ini adalah penelitian hukum normatif empiris. Hasil penelitian menunjukkan bahwa penerapan Perma Nomor 2 Tahun 2015 dan Perma Nomor 4 Tahun 2019 tentang Tata Cara Penyelesaian Gugatan Sederhana di Pengadilan Negeri Selong terlaksana secara efektif dengan kendala-kendala yang lebih disebabkan oleh kelemahan Perma itu sendiri secara internal. 


\section{A. PENDAhUlUan}

Penegakan hukum dalam negara hukum seperti Indonesia, merupakan hal yang penting untuk dapat menciptakan keadilan dalam masyarakat sesuai dengan tujuan pembangunan nasional Indonesia. Negara hukum dalam menjalankan pemerintahan memerlukan suatu lembaga peradilan untuk menjaga agar tetap tegaknya hukum dan keadilan. Lembaga peradilan merupakan tempat penyelesaian suatu permasalahan atau perkara baik berupa masalah tindak pidana maupun sengketa perdata.

Sengketa perdata merupakan salah satu contoh perselisihan yang sering terjadi di masyarakat. Sengketa Perdata diakibatkan oleh ketimpangan kewajiban dan hak dari pihak-pihak yang terlibat dalam suatu perjanjian sehingga menyebabkan salah satu pihak mengalami kerugian yang sifatnya nyata maupun hilangnya keuntungan yang diharapkan dari suatu perjanjian tersebut dimana dalam hal ini disebut dengan cidera janji (wanprestasi)". Sehingga dalam hal ini banyaknya masyarakat yang memilih jalur litigasi untuk penyelesaian sengketa, baik sengketa ringan maupun yang berat yang menjadi penyebab utama penumpukan perkara di peradilan tingkat pertama, peradilan tingkat banding, apalagi di peradilan tingkat kasasi (Mahkamah Agung).

Akibat dari penumpukan perkara yang telah diuraikan diatas merupakan salah satu masalah terbesar di lingkungan peradilan yang juga menyebabkan tidak efektifnya pelaksanaan peradilan sesuai dengan asas Trilogi Peradilan yang meliputi peradilan cepat, sederhana, dan biaya ringan. Mahkamah Agung mengeluarkan kebijakan strategis untuk mengantisipasi masalah tersebut, yaitu dengan cara menerapkan sistem gugatan sederhana yang diadopsi dari penerapan small claim court di beberapa negara salah satunya negara Amerika Serikat dan Australia. Mahkamah Agung Republik

\footnotetext{
${ }^{1}$ Subekti, Hukum Perjanjian. Jakarta : Intermasa, 2001.
}

Indonesia meregulasinya dalam Peraturan Mahkamah Agung (Perma) Nomor 2 Tahun 2015, yang telah diundangkan pada tanggal 7 Agustus Tahun 2015 tentang Tata Cara Penyelesaian Gugatan Sederhana jo Perma Nomor 4 Tahun 2019 Tentang Perubahan Atas Perma Nomor 2 Tahun 2015 Tentang Tata Cara Penyelesaian Gugatan Sederhana yang telah diundangkan pada tanggal 20 Agustus 2019.

Perma Nomor 2 Tahun 2015 dan Perma Nomor 4 Tahun 2019 tersebut merupakan upaya mengoptimalkan penyelesaian gugatan sederhana (small claim court) agar lebih sederhana, cepat dan biaya ringan. Secara teoritis, Small Claim Court merupakan langkah yang tepat untuk membenahi permasalahan penumpukan perkara di peradilan. Namun pada kenyataannya penerapan sistem gugatan sederhana belumlah menjadi pilihan, karena masih banyak masyarakat yang belum tahu atau masih awam tentang gugatan sederhana sehingga mereka tetap memilih menggunakan jalur litigasi konvensional.

Berdasarkan latar belakang masalah yang dikemukakan diatas, maka dapat dirumuskan masalah sebagai berikut : Pertama, bagaimana penerapan gugatan sederhana (small claim court) untuk penyelesaian perkara wanprestasi di Pengadilan Negeri Selong. Kedua, apa saja kendala yang dihadapi gugatan sederhana (small claim court) untuk penyelesian perkara wanprestasi di Pengadilan Negeri Selong.

\section{B. METODE PENELITIAN}

Penelitian ini menggunakan metode normatif empiris, dimana metode normatif merupakan penelitian hukum yang berdasarkan pada doktriner sehingga penilitian ini disebut juga penelitian perpustakaan. Sedangkan penelitian hukum empiris adalah suatu metode penelitian hukum yang melihat hukum secara riil dan bagaimana penerapan serta respon 
masyarakat terhadapnya. penelitian ini lebih pada melihat hukum secara Ius constitutum dan Ius constituendum. ${ }^{2}$

Pendekatan yang digunakan, diantaranya pendekatan perundang-undangan (statute approach), pendekatan Konseptual (conseptual approach) dan pendekatan sosio legal (pendekatan sosiologis), pendekatan yang dilakukan dengan cara mengkaji penerapan hukum dalam pelaksanaan gugatan sederhana yang meliputi masyarakat baik perorangan maupun yang berbadan hukum yang mengajukan gugatan sederhana pada Pengadilan Negeri Selong. ${ }^{3}$

Sumber data dalam penelitian ini adalah data Primer adalah data yang diperoleh secara langsung dari lapangan, baik dengan observasi dan wawancara. Data sekunder adalah data yang diperoleh melalui studi pustaka yang bertujuan untuk memperoleh landasan teori yang besumber dari peraturan perundang-undangan, data arsip dokumen yang ada hubungannya dengan obyek penelitian. Teknik pengumpulan data yang digunakan adalah melalui studi dokumentasi dan melalui penelusuran literatur serta dengan melakukan teknik wawancara dan observasi. Menurut Soerjono Soekanto dalam penelitian lazimnya dikenal tiga jenis alat pengumpul data, yaitu studi dokumen atau bahan pustaka, pengamatan atau observasi dan wawancara atau interview. Studi Dokumentasi diberi pengertian sebagai langkah awal dari setiap penelitian hukum (baik normatif maupun yang sosiologis). ${ }^{4}$

Analisis data merupakan tahap yang paling penting dalam suatu penelitian karena dalam penelitian ini data yang diperoleh akan diproses dan dimanfaatkan sedemikian rupa sampai didapat suatu kesimpulan yang nantinya akan menjadi hasil akhir penelitian.

\footnotetext{
2 Soerjono Soekanto dan Purnadi Purbacaraka, Aneka Cara Pembedaan Hukum, (Bandung: PT Citra Aditya Bakti, 1994), Hal. 5

3 Peter Mahmud Marzuki, Penelitian Hukum, Cet.2, (Jakarta: Kencana Prenada Media Group, 2005), Hal. 93-137.

4 Soerjono Soekanto. Pengantar Penelitian Hukum. Jakarta. UI-Press, 2010, hal.21-25
}

Data yang dikumpulkan dari hasil penelitian kemudian dianalisis oleh penulis secara deskriptif-kualitatif, artinya data-data hasil yang dilakukan oleh penulis digunakan untuk menentukan isi atau makna aturan hukum yang dijadikan rujukan dalam menyelesaikan permasalahan hukum yang menjadi objek kajian. Sedangkan kualitatif artinya penelitian yang mengacu pada norma-norma yang hidup dan berkembang dalam masyarakat. Pendekatan kualitatif ini terpusat pada prinsip umum yang mendasari perwujudan satuansatuan gejala sosial budaya, sehingga suatu gambaran hasil penelitian lengkap, informasi yang di sampaikan nampak hidup yang bersifat grounded berpijak betul pada sebuah kenyataan yang ada, sesuai dengan kejadian yang sebenarnya. ${ }^{5}$

\section{PEMBAHASAN}

Peradilan dilakukan dengan sederhana, cepat dan biaya ringan merupakan salah satu asas dalam Hukum Acara Perdata yang tertuang dalam Pasal 2 ayat (4) UndangUndang Nomor 48 Tahun 2009 tentang Kekuasaan Kehakiman (UU No. 48 Tahun 2009). Asas tersebut dikenal dengan sebutan "Asas Trilogi Peradilan", memberikan jaminan dalam proses penyelesaian perkara di pengadilan untuk diselesaikan dalam waktu yang singkat, tidak berbelit-belit, dan dengan biaya yang tidak memberatkan masyarakat yang berperkara.

Aturan perdata di Indonesia berpedoman pada HIR dan RBg dalam proses penanganan perkara perdata di pengadilan. Sementara itu, kedua aturan ini (HIR dan RBg) tidak mengenal penyelesaian perkara secara sederhana, cepat dan singkat sesuai asas peradilan berdasarkan Pasal 2 ayat (4) UU No. 48 Tahun 2009. Keduanya, baik HIR maupun RBg yang membedakan hanya jenis dan kategori perkara melalui pengajuan gugatan dan melalui permohonan.

5 Burhan Ashshofa, Metode Penelitian Hukum, Penerbit Rineka Cipta, 2001, Hal 21. 
Berlandaskan Pasal 24D UUD 1945, Mahkamah Agung (MA) memiliki wewenang menggadili ditingkat kasasi, menguji peraturan perundang-undangan di bawah Undang-Undang, serta memegang kekuasaan lainnya yang diberikan UU. Undang-Undang memberikan kekuasaan kepada MA dalam menerbitkan suatu regulasi yang berfungsi mengisi kekosongan ataupun pelengkap kekurangan aturan terhadap hukum acara untuk memperlancar pengendalian yustisi.

Aturan yang di dapat berdasarkan delegasi kewenangan dinamakan Peraturan Mahkamah Agung yang biasa disingkat dengan PERMA diterbitkan pertama kali pada tahun 1954. Terkait eksistensi PERMA ditemukan tiga hal yang patut dicermati, yaitu kewenangan MA sebagai lembaga yudikatif, di dalam mengeluarkan sebuah peraturan yang terkadang memiliki karakteristik sebagai suatu perundangundangan, kedudukan PERMA di dalam sistem perundang-undangan Indonesia, dan tentang peranan peraturan itu di dalam memenuhi kebutuhan penyelenggaraan pemerintahan, khususnya di bidang peradilan. ${ }^{6}$

Pasal 8 ayat (2) Undang-Undang Nomor 12 Tahun 2011 tentang Pembentukan Peraturan Perundang-undangan telah mengakui keberadaan PERMA sebagai salah satu jenis peraturan perundang-undangan dan mempunyai kekuatan hukum yang mengikat sepanjang diperintahkan langsung oleh Peraturan Perundang-undangan yang lebih tinggi dan dibentuk berdasarkan kewenangan. $^{7}$

Berdasarkan kewenangan tersebut, MA mengeluarkan kebijakan untuk mengantisipasi berbagai masalah penyelesaian segketa yang sederhana, cepat

\footnotetext{
${ }^{6}$ Diambil dari website resmi bphn, tersedia di :http://www.bphn.go.id/data/documents/eksistensi peratu ran perundang-undangan.pdfdiakses pada tanggal 11September 2020, Pukul 09:16

7 Republik Indonesia, Undang-Undang Nomor 12 Tahun 2011tentang Pembentukan Peraturan Perundang Undangan, Pasal 8 ayat (2)
}

dan biaya ringan, meregulasinya dalam Perma No. 2 Tahun 2015 yang telah diundangkan pada tanggal 7 Agustus Tahun 2015 tentang Tata Cara Penyelesaian Gugatan Sederhana sebagaimana telah dirubah dengan Perma No. 4 Tahun 2019 tentang Perubahan Atas Perma No. 2 Tahun 2015 Tentang Tata Cara Penyelesaian Gugatan Sederhana, yang diundangkan pada tanggal 20 Agustus 2019.

Perma No. 2 Tahun 2015 dan Perma No. 4 Tahun 2019 merupakan suatu bentuk upaya dalam mengoptimalkan penyelesaian gugatan sederhana (small claim court) agar lebih sederhana, cepat dan biaya ringan. Secara teoritis, Small Claim Court merupakan langkah yang tepat untuk membenahi permasalahan penumpukan perkara di Peradilan.

\section{Pengertian Gugatan Sederhana (Small ClaimCourt)}

Menurut M. Natsir Asnawi, Gugatan Sederhana (Small Claim Court) adalah gugatan dalam bidang hukum perdata yang nilai gugatan materilnya paling banyak Rp. 200.000.000,- (dua ratus juta rupiah) yang diselesaikan dengan tata cara dalam pembuktian sederhana (simple procedure and

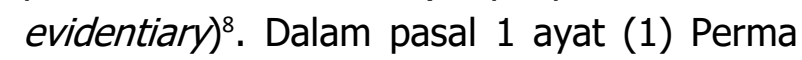
No. 2 Tahun 2015 disebutkan bahwa "penyelesaian gugatan sderhana adalah tata cara di persidangan terhadap gugatan perdata dengan nilai materil paling banyak Rp. 200.000.000, - (dua rtus juta rupiah) yang diselesaikan dengan tata cara dan pembuktian yang sederhana."

Mahkamah Agung

telah menyempurnakan aturan tersebut dengan menerbitkan Perma Nomor 4 Tahun 2019 tentang Perubahan Atas Perma Nomor 2 Tahun 2015 tentang Tata Cara Penyelesaian Gugatan Sederhana, dimana Ketentuan Pasal 1 angka 1 dan Pasal 3 ayat (1) diubah, sehingga berbunyi sebagai berikut:

8 M. Natsir Asnawi, Hukum Acara Perdata : Teori dan Praktik. Jakarta . 2016. HIm. 648 
"penyelesaian gugatan sederhana adalah tata cara pemeriksaan di persidangan terhadap gugatan perdata dengan nilai gugatan materiil paling banyak Rp. 500.000.000,00 (lima ratus juta rupiah) yang diselesaikan dengan tata cara dan pembuktiannya sederhana.

Sistem Gugatan Sederhana (Small Claim Court) di Indonesia tergolong masih baru, keberadaannnya secara yuridis formal ditandai dengan diundangkannya Perma No. 2 Tahun 2015 pada tanggal 7 Agustus 2015 melalui Berita Negara Republik Indonesia Tahun 2015 Nomor 1172.

Perma No. 2 Tahun 2015 ini terdiri dari 9 (sembilan) Bab dan 33 (tiga puluh tiga) pasal, pada tahun 2019 Ketua Mahkamah Agung telah menetapkan Perma No. 4 Tahun 2019 tentang Perubahan atas Perma No. 2 Tahun 2015 Tentang Tata Cara Penyelesaian Gugatan Sederhana dan diundangkan pada tanggal 20 Agustus 2019.

\section{Penyelesaian Gugatan Sederhana}

Dalam penyelesaian perkara gugatan sederhana, terdapat beberapa tahapantahapan yang harus dilalui selama persidangan. Prosedur dan tata cara dari pelaksanaan hukum acara tersebut telah diatur dalam Perma No. 2 Tahun 2015 dan Perma No. 4 Tahun 2019. Pemeriksaan diawali dengan pendaftaran gugatan di Kepaniteraan Pengadilan Negeri yang berkewenangan mengadili perkara dan diakhiri dengan pembacaan putusan oleh hakim tunggal. Terlebih dahulu Panitera menentukan kualifikasi perkaranya dengan menganalisa dan menilai apakah gugatan yang diajukan merupakan gugatan yang dapat diperiksa dengan penyelesian gugatan sederhana atau merupakan gugatan yang diperiksa dengan acara perdata biasa. Apabila ternyata perkara tersebut termasuk dalam obyek gugatan sederhana maka akan dilanjutkan dengan pemeriksaan pendahuluan dan sebaliknya jika tidak termasuk gugatan sederhana, maka Ketua
Pengadilan Negeri akan mengeluarkan penetapan desmissal (pendahuluan).

Adapun alur dan tahapan-tahapan hukum acara dalam penyelesaian gugatan sederhana yang telah diatur dalam Pasal 5 ayat (2) Perma No. 2 Tahun 2015 dan Perma No. 4 Tahun 2019 adalah sebagai berikut: ${ }^{9}$

(1) Gugatan sederhana diperiksa dan diputus oleh hakim tunggal yang ditunjuk oleh Ketua Pengadilan.

(2) Tahapan Penyelesaian Gugatan Sederhana meliputi :

(1) Pendaftaran;

(2) Pemeriksaan kelengkapan gugatan sederhana;

(3) Penetapan Hakim Tunggal dan Penunjukan Panitera Pengganti;

(4) Pemeriksaan Pendahuluan;

(5) Penetapan Hari Sidang dan Pemanggilan Para Pihak;

(6) Pemeriksaan Sidang dan upaya perdamaian

(7) Pembuktian, dan

(8) Putusan.

Khusus mengenai pedaftaran gugatan, berdasarkan Perma No. 1 Tahun 2019 tentang Tata Cara Pelaksanaan Sidang Eleketronik (e-court) yang mengatur semua perkara didaftarkan melalui melalui $e$-court, baik itu perkara perdata biasa maupun perkara gugatan sederhana. Terkait dengan itu, dalam Pasal 6A Perma No. 4 Tahun 2019 menyebutkan: "Penggugat dan tergugat dapat menggunakan administrasi perkara di pengadilan secara elektronik sesuai dengan ketentuan peraturan perundangundangan".

(3) Penyelesaian gugatan sederhana paling lama 25 (dua puluh lima) hari sejak hari sidang pertama.

Setelah perkara diputus pihak yang kalah dalam mengajukan penyelesaian upaya hukum keberatan dilakukan dalam waktu 24

9 Republik Indonesia, Perma Nomor 2 Tahun 2015 tentang Tata Cara Penyelesaian Gugatan Sederhana, Pasal 5 ayat (2). 
hari kerja. Jangka waktu dihitung sejak pembacaan atau pemberitahuan putusan sampai dengan pemberitahuan putusan keberatan. dengan perincian sebagai berikut:

1) Para pihak yang tidak setuju atau keberatan dengan hasil putusan, mengajukan keberatan beserta alasan atau memori keberatan kepada Ketua Pengadilan Negeri dalam waktu paling lama 7 (tujuh) hari kerja sejak putusan tersebut dibacakan, atau paling lama 7 (tujuh) hari kerja setelah pemberitahuan isi putusan. Apabila upaya hukum keberatan diajukan lewat dari jangka waktu tersebut akan dinyatakan tidak dapat diterima melalui Penetapan Ketua Pengadilan Negeri berdasarkan Surat Keterangan Panitera.

2) Panitera memeriksa kelengkapan berkas permohonan keberatan dan menyerahkan Memori Keberatan kepada Termohon paling lambat tiga (3) hari sejak permohonan keberatan diajukan.

3) Termohon menyampaikan Kontra Memori Keberatan paling lambat tiga (3) hari sejak menerima Memori Keberatan Pemohon.

4) Ketua Pengadilan menetapkan Majelis Hakim dalam waktu 1 (satu) hari setelah permohonan dinyatakan lengkap.

5) Majelis Hakim mengucapkan putusan dalam waktu paling lambat 7 (tujuh) hari sejak Penetapan Majelis.

6) Panitera menyampaikan salinan Putusan Keberatan kepada para pihak paling lambat 3 (tiga) hari sejak putusan keberatan dibacakan.

3. Penerapan Gugatan Sederhana (Small Claim Court) untuk Penyelesaian Perkara Wanprestasi di Pengadilan Negeri Selong.

Sejak dikeluarkannya Perma No. 2 Tahun 2015 dan Perma No. 4 Tahun 2019, Pengadilan Negeri Selong telah membuka dan memberikan pelayanan kepada masyarakat pencari keadilan untuk menyelesaikan permasalahannya melalui jalur gugatan sederhana. Dari tahun 2016 sampai dengan bulan juli tahun 2020, jumlah perkara gugatan sederhana yang diajukan di Pengadilan Negeri Selong sebanyak 94 perkara. Dari 94 jumlah perkara tersebut gugatan sederhana klasifikasi Perbuatan Melawan Hukum (PMH) sebanyak 34 perkara dan klasifikasi wanprestasi sejumlah 60 perkara.

Berikut ini penulis sajikan dalam bentuk tabel jumlah keseluruhan perkara gugatan sederhana di Pengadilan Negeri Selong sejak dikeluarkannya Perma No. 2 Tahun 2015 terakhir dirubah dengan Perma No. 4 Tahun 2019.

Tabel 1 : Perkara Gugatan Sederhana di Pengadilan Negeri Selong dari tahun 2016 s.d. Juli 2020

\begin{tabular}{|l|c|c|c|c|c|}
\hline \multirow{2}{*}{ No } & \multirow{2}{*}{ Tahun } & \multicolumn{2}{|c|}{$\begin{array}{c}\text { Klasfikasi Gugatan } \\
\text { Sederhana }\end{array}$} & Total & Ket \\
\cline { 3 - 6 } & & Wanprestasi & PMH & & \\
\hline 1. & 2016 & 1 & & 1 & \\
\hline 2. & 2017 & 5 & & 5 & \\
\hline 3. & 2018 & 21 & 4 & 25 & \\
\hline 4. & 2019 & 27 & 26 & 53 & \\
\hline 5. & 2020 & 6 & 4 & 10 & $\begin{array}{l}\text { Sampai } \\
\text { bulan juli } \\
2020\end{array}$ \\
\hline \multicolumn{2}{|c|}{ Total } & 60 & $\mathbf{3 4}$ & & \\
\hline
\end{tabular}

Sumber : Kepaniteraan Pengadilan Negeri Selong

Adapun mekanisme dan prosedur penyelesaian gugatan sederhana (smaal claim court) secara umum yang ada di Pengadilan Negeri Selong dapat penulis paparkan sebagai berikut :

\subsection{Ruang Lingkup Gugatan Sederhana (Small Claim Court)}

Ruang lingkup gugatan sederhana dijelaskan dalam Pasal 3 Peratuan Mahkamah Agung No. 2 Tahun 2015 terakhir dirubah dengan Peraturan Mahkamah Agung No.4 Tahun 2019 yang berbunyi:

(1) Gugatan sederhana diajukan terhadap perkara cidera janji dan/atau perbuatan melawan hukum dengan nilai gugatan gugatan materiil paling banyak Rp. 500.000 .000 (lima ratus juta rupiah)

(2) Tidak termasuk gugatan sederhana 
adalah :
a. Perkara
yang
penyelesaian
sengketanya dilakukan melalui pengadilan khusus sebagaimana diatur di dalam peraturan-perundang- undangan; atau
b. Bukan sengketa hak atastanah.

Selanjutnya tentang para pihak dalam perkara gugatan sederhana diatur dalam ketentuan Pasal 4 berbunyi:

(1) Para pihak dalam gugatan sederhana terdiri dari Penggugat dan Tergugat yang masing-masing tidak lebih dari satu, kecuali memiliki kepentingan hukum yang sama;

(2) Tergugat yang tidak diketahui tempat tinggalnya, tidak dapat diajukan gugatan sederhana;

(3) Penggugat dan tergugat dalam gugatan sederhana berdomisili di daerah hukum Pengadilan yang sama;

(4) Dalam hal penggugat berada di luar wilayah hukum tempat tinggal atau domisili tergugat, penggugat dalam mengaukan gugatan menunjuk kuasa, kuasa insidentil, atau wakil yang beralamat di wilayah hukum atau domisili tergugat dengan surat tugas dari institusi penggugat;

(5) Penggugat dan tergugat wajib menghadiri secara langsung setiap persidangan dengan atau tanpa didampingi oleh kuasa, kuasa insidentil, atau wakil yang beralamat di wilayah hukum atau domisili tergugat dengan surat tugas dari institusi penggugat.

Dari ketentuan pasal 3 dan pasal 4 di atas, beberapa hal yang perlu diperhatikan dalam mengajukan gugatan sederhana yakni : kriteria perkara yang diajukan melalui gugatan sederhana hanya 2 (dua) klasifikasi, yaitu perkara klasifikasi wanprestasi dan perkara klasifikasi Perbuatan Melawan Hukum (PMH) yang nilai materiil obyek gugatannya tdak boleh melampaui batas Rp. 500.000.000,- (lima ratus juta rupiah). pada segi obyek gugatan bukan mengenai sengketa hak kepemilikan atas tanah, sedangkan dari dari segi kompetensi pengadilan, perkara yang diajukan bukan perkara yang penyelesaiannya dilakukan melalui peradilan khusus.

Selanjutnya dari segi subyek atau para pihak dengan ketentuan harus bertempat tinggal pada wilayah peradilan yang sama, jikalaupun yang menggugat tinggal/berdomisili kawasan yang berbeda dengan pihak yang digugat maka yang menggugat dapat mewakilkan kepada kuasa (advokat dan/atau kuasa insidentil) yang berdomisili di daerah hukum yang sama dengan tergugat. Selain itu, ditegaskan para pihak harus hadir dalam setiap persidangan secara langsung, walaupun para pihak telah mewakilkan atau menggunakan jasa kuasa hukum.

Pengadilan Negeri Selong dalam menyelesaikan perkara gugatan sederhana berpedoman pada ketentuan dalam Pasal 3 dan Pasal 4 di atas. Dalam wawancara penulis dengan Julius Bolla, Panitera Pengadilan Negeri Selong dalam wawancara menjelaskan tentang ruang lingkup yang dikatakan sebagai syarat-syarat dalam mengajukan gugatan sederhana di antaranya : "Nilai gugatan materiil menurut Perma No 2 Tahun 2015 paling banyak Rp. 200.000.000,00 (dua ratus juta ruiah) dan ketentuan ini telah dirubah berdasarkan Perma No. 4 Tahun 2019 yang menyebutkan nilai materiil gugatan sederhana paling banyak Rp. 500.000.000 (lima ratus juta rupiah)". Apabila keseluruhan persyaratan tersebut dipenuhi, maka perkara yang diajukan ke pengadilan oleh penggugat akan diselesaikan melalui penyelesaian gugatan sederhana. Apabila ada persyaratan yang tidak terpenuhi, maka gugatan dikembalikan kepada penggugat. Selanjutnya sesuai Perma No 2 Tahun 2015 terakhir dirubah dengan Perma No. 4 tahun 2019 para pihak yang berperkara bisa antara perorangan dengan perorangan, perorangan dengan badan hukum, dan bisa juga antara badan hukum 
dengan badan hukum yang memenuhi persyaratan gugatan sederhana. Sementara itu, yang dimaksud dengan kepentingan hukum yang sama adalah kepentingan yang saling terkait antara sesama penggugat atau tergugat. Sebagai contoh, dalam perjanjian kredit, suami yang menanda tangani perjanjian kredit yang dilakukan oleh istri merupakan pihak yang masuk dalam kategori kepentingan hukum yang sama dalam sengketa perdata tersebut". ${ }^{10}$

\subsection{Tahapan Penyelesaian Gugatan Sederhana di PN Selong}

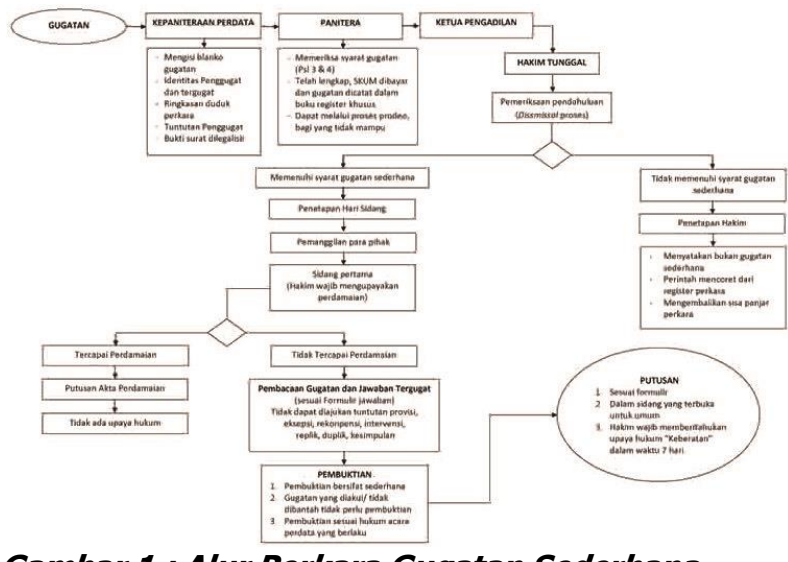

Gambar 1 : Alur Perkara Gugatan Sederhana

\section{a. Pendaftaran}

Berdasarkan ketentuan Pasal 6 Perma No. 2 Tahun 2015 dan Perma No. 4 Tahun 2019 yang berbunyi :

(1) Penggugat mendaftarkan gugatannya di kepaniteraan pengadilan;

(2) Penggugat dapat mendaftarkan gugatannya dengan mengisi blangko gugatan yang disediakan di kepaiteraan;

(3) Blangko gugatan berisi keterangan mengenai:
a. identitas penggugat dan tergugat;
b. penjelasan ringkas duduk perkara, dan
c. tuntutan penggugat.

(4) Penggugat wajib melampirkan bukti surat yang sudah dilegalisasi pada saat mendaftarkan gugatan sederhana.

\footnotetext{
10 Wawancara dengan Julius Bolla, Panitera Pengadilan Negeri Selong pada hari Rabu, tanggal 19 Agustus Tahun 2020
}

Dalam praktik pendaftaran perkara gugatan sederhana di Pegadilan Negeri Selong, format gugatan yang dibuat oleh peggugat tidak menggunakan format gugatan sederhana yang telah disediakan. Format dan struktur gugatan yang dibuat dengan menampilkan ciri-ciri masing-masing, namun demikian secara substansi tidak meyimpangi ketentuan yang ada.

Selain itu, Pasal 6 ayat (4) mewajibkan penggugat melampirkan bukti surat yang sudah dilegalisasi pada saat pendaftaran gugatan sederhana. Pada perkara perdata biasa, alat bukti diajukan pada saat hari sidang yang ditentukan waktunya untuk pengajuan alat bukti. Begitu juga, pada saat pengajuan gugatan sederhana alat bukti berupa identitas saksi dan keterangan saksi dilampirkan pada saat pegajuan (pendaftaran) gugatan.

Praktik lainnya, sejak dikeluarkannya Perma No. 1 Tahun 2019 tentang Tata Cara Pelaksanaan Sidang Eleketronik (e-court), semua perkara didaftarkan di Pegadilan Negeri Selong melalui melalui e-court, baik itu perkara perdata biasa maupun perkara gugatan sederhana. Disebutkan dalam Pasal 6A Perma No. 4 Tahun 2019: "Penggugat dan tergugat dapat menggunakan administrasi perkara di pengadilan secara elektronik sesuai dengan ketentuan peraturan perundang-undangan".

Terkait dengan pendaftaran gugatan melalui e-court, wawancara penulis degan Bapak Julius Bolla Ketua Panitera Pengadilan Negeri Selong mengatakan: "Semua pendaftaran gugatan dilakukan melalui aplikasi e-court, bagi penggugat yang belum mampu menggunakan aplikasi e-court pengadilan menyiapkan petugas untuk membantu proses pendaftaran gugatan menggunakan aplikasi e-court ${ }^{\text {m11. }}$.

\section{b. Pemeriksaan Gugatan Sederhana}

Pemeriksaan berkas gugatan, setelah

11 Wawancara dengan Julius Bolla, Panitera Pengadilan Negeri Selong pada hari rabu, tanggal 19 Agustus tahun 2020 
proses pendaftaran selesai, tahapan berikutnya adalah pemeriksaan berkas pendaftaran gugatan oleh panitera. Hal-hal yang diperiksa dalam tahapan pemeriksaan berkas gugatan perihal syarat pendaftaran gugatan, apakah sesuai atau tidak dengan ketentuan Pasal 3 dan Pasal 4. Pemeriksaan berkas gugatan tercantum pada Peraturan Mahkamah Agung No. 2 Tahun 2015 pasal 7 yang berbunyi :

(1) Panitera melakukan pemeriksaan syarat pendaftaran gugatan sederhana berdasarakan ketentuan Pasal 3 dan Pasal 4 peraturan ini;

(2) Panitera mengembalikan gugatan yang tidak memenuhi syarat sebagaimana dimaksud pada ayat (1);

(3) Registrasi perkara permohonan sederhana dicatat dalam buku register khusus gugatan sederhana.

Terkait dengan berkas gugatan sederhana yang dikembalikan oleh penitera (Pasal 7 ayat (2) di atas), dapat diajukan kembali oleh penggugat dengan mendaftar kembali gugatannya mengikuti prosedur dari awal. Selain itu, berkas perkara yang dikembalikan tersebut, oleh penggugat dapat juga didaftarkan melalui gugatan biasa. Hal ini sebagaimana dikatakan oleh Julius Bolla, Panitera Pengadilan Negeri Selong, "Apabila berkas dinyatakan tidak memenuhi persyaratan gugatan sederhana, maka berkas dikembalikan dan/atau disarankan untuk dicabut oleh penggugat dan dapat diajukan kembali sepanjang memenuhi persyaratan gugatan sederhana. Sedangkan untuk beracara secara cuma-cuma (prodeo) untuk perkara yang diajukan melalui gugatan sederhana sampai penelitian ini berlangsung belum ada di Pengadilan Negeri Selong".12

Penerapan pemeriksaan berkas gugatan sederhana di Pengadilan Negeri Selong terlihat pada perkara gugatan sederhana kriteria wanprestasi No. 3/Pdt.G.S/2020/PN.Sel, tertanggal 15 Januari

12 Wawancara dengan Julius Bolla, Panitera Pengadilan Negeri Selong pada hari rabu, tanggal 19 Agustus tahun 2020
2020 yang sebelumnya pernah diajukan karena tidak memenuhi syarat (dismissal), kembali diajukan. Hasil pemeriksaan berkas gugatan, ditemukan salah satu tergugat tidak berdomisili di wilayah hukum yang sama dengan penggugat. Atas temuan tersebut panitera menyarankan kepada kuasa hukum penggugat untuk memperbaiki gugatannya dan dapat diajukan kembali setelah memenuhi ketentuan yang ada. Atas saran dari panitera tersebut, penggugat memperbaiki gugatannya, kemudian diajukan kembali dengan mengikuti prosedur pendaftaran dari awal. Dan karena gugatan dinilai oleh penitera telah memenuhi kriteria gugatan sederhana dalam pemeriksaan berkas gugatan, kemudian panitera mencatat dalam buku register perkara dengan Nomor Register 3/Pdt.G.S/2020/PN.Sel, tertanggal tertanggal 15 Januari 2020.

Zainul Fikri, SH kuasa hukum penggugat Perkara Nomor: 3/Pdt.G.S/2020 mengatakan: "Pada awal bulan januari 2020 perkara ini pernah diajukan dan dari pemeriksaan berkas yang dilakukan oleh panitera, pantera mengingatkan agar gugatan sebaiknya diperbaiki dan diajukan kembali, karena alamat salah satu tergugat berdomisili di wilayah hukum yang berbeda dengan penggugat. Atas saran dari paniter, kami memperbaiki gugatan dan setelah diperbaiki pada tanggal 13 Januari 2020 diajukan/didaftarkan kembali dengan mengikuti prosedur dari awal". ${ }^{13}$

Sedangkan apabila hasil pemeriksaan berkas gugatan dinyatakan memenuhi persyaratan sebagaimana dimaksud dalam Pasal 3 dan Pasal 4, panitera mencatat gugatan tersebut dalam buku register khusus gugatan sederhana. Dan berdasakan Pasal 8 ayat (1) dan ayat (2) di atas, ketua pengadilan kemudian menetapkan panjar biaya yang mana panjar biaya tersebut wajib dibayar oleh penggugat.

\footnotetext{
${ }^{13}$ Wawancara dengan Zainl Fikri, SH, Kuasa Hukum Penggugat Perkara No. 3/Pdt.GS/2020/PN.Sel pada hari Jumat, tanggal 21 Agustus tahun 2020
} 


\section{c. Penetapan Hakim dan Penunjukan Panitera Pengganti}

Penetapan hakim dilakukan oleh ketua pengadilan setelah panjar biaya perkara selesai dibayarkan oleh penggugat. Hakim yang memeriksa dan memutus perkara gugatan sederhana adalah hakim tunggal. Dalam Pasal 9 No. 2 tahun 2015 perihal penetapan hakim dalam gugatan sederhana yang menyebutkan bahwa:

(1) Ketua pengadilan menetapkan Hakim untuk memeriksa gugatan sederhana.

(2) Panitera menunjuk panitera pengganti untuk membantu Hakim dalam memeriksa gugatan sederhana.

Selanjutnya ketentuan mengenai jumlah hakim pada perkara gugatan sederhana diatur dalam Pasal 1 ayat (3) Perma No. 4 Tahun 2019 yang menyebutkan "bahwa hakim adalah hakim tunggal". Ketentuan tentang hakim dalam perkara gugatan sederhana dapat ditemukan dalam Bimbingan Teknis Penyelesaian Perkara Gugatan Sederhana Direktoral Jenderal Badan Peradilan Umum Mahkamah Agung Republik Indonesia Tahun 2015 yang meyebutkan: "Perkara gugatan sederhana diperiksa dan diputus dalam 2 (dua) tingkatan oleh pengadilan negeri yang sama. Pada tingkat pertama, perkara diperiksa dan diputus oleh hakim tunggal. Sedangkan pada tingkat upaya hukum keberatan diperiksa dan diputus oleh majelis hakim". ${ }^{14}$

\section{d. Pemeriksaan Pendahuluan}

Pemeriksaan pendahuluan merupakan pemeriksaan yang dilakukan oleh hakim sebelum jadwal sidang ditetapkan. Materi yang dinilai pada pemeriksaan pedahuluan pada dasarnya sama dengan pemeriksaan berkas gugatan yakni apakah gugatan sederhana telah memenuhi atau tidak memenuhi ketentuan dalam Pasal 3 dan Pasal 4. Pemeriksaan pendahuluan tercantum

\footnotetext{
${ }^{14}$ Direktoral Jenderal Badan Peradilan Umum Mahkamah agung Republik Indonesia, Bimbingan Teknis Penyelesaian Perkara Gugatan Sederhana, 2015. hlm 4
}

pada Pasal 11 Perma No. 2 Tahun 2015 yang selengkapnya berbunyi :

(1) Hakim memeriksa materi gugatan sederhana berdasarkan syarat sebagaimana dimaksud dalam ketentuan Pasl 3 dan Pasal 4 peraturan ini;

(2) Hakim menilai sederhana atau tidaknya pembuktian;

(3) Apabila dalam pemeriksaan, Hakim berpendapat bahwa gugatan tidak termasuk dalam gugatan sederhana, maka Hakim mengeluarkan penetapan yang menyatakan bahwa gugatan bukan gugatan sederhana, mencoret dari register perkara dan memerintahkan pengembalian sisa biaya perkara kepada penggugat;

(4) Terhadap penetapan sebagaimana dimaksud pada ayat (3) tidak dapat dilakukan upaya hukum apapun.

Berdasarkan ketentuan Pasal 11 di atas, bahwa dalam penyelesaian perkara gugatan sederhana terdapat pemeriksaan pendahuluan sebelum ditetapkan jadwal persidangan. Pemeriksaaan pendahuluan ini selain merupakan proses yang mendukung kelancaran dan efektifitas pelaksanaan pemeriksaan sampai putusan yang hanya memiliki batas waktu 25 hari kerja juga manfaatnya dirasakan sangat membantu meringankan penggugat.

Hal ini dikatakan oleh Zainul Fikri, $\mathrm{SH}$, salah seorang advokat yang sering mendampingi perkara gugatan sederhana : "Pemeriksaan pendahuluan ini sangat efektif dan efisen baik dilihat dari materiil biaya yang dikeluarkan penggugat maupun waktu yang dialokasikan selama 25 hari. Apabila gugatan ada kekurangan langsung diputus berupa ketetapan hakim yang menyatakan gugatan bukan gugatan sederhana tidak menunggu putusan yang melewati proses waktu 25 hari. Padahal nilai putusannya sama-sama akan menolak gugatan".15

15 Wawancara dengan Zainul Fikri, SH, advokat pada Kantor BM\&Patners, Advokate\&Legal Consultant pada hari Jumat, tanggal 21 Agustus Tahun 2020. 
Hal penting lainnya dalam pemeriksaan pendahuluan dapat dilihat dari pemeriksaan alat bukti surat oleh hakim, yang mana hakim menilai apakah bukti surat yang diajukan tersebut sederhana atau tidak untuk diperiksa dan diputus melalui penyelesaian perkara gugatan sederhana. Pemeriksaan bukti surat dalam pemeriksaan penduhuluan ini menjadi dasar dilampirkannya bukti surat oleh penggugat pada saat pendaftaran gugatan sederhana bersifat wajib.

Penerapan pemeriksaan pendahuluan dengan putusan (penetapan) di Pengadilan Negeri Selong terdapat 4 (empat) perkara wanprestasi dan 2 (dua) perkara PMH yang dikeluarkan Penetapan Dismissal (gugur) oleh Ketua Pengadilan Negeri Selong. Dalam wawancara penulis dengan Bapak Timur Agung Nugroho, S.H, M.H, Hakim Tunggal perkara gugatan sederhana Pengadilan Negeri Selong, menjelaskan bahwa: "Perkaraperkara gugatan sederhana klasifikasi wanprestasi yang diputus pada saat pemeriksaan pendahuluan karena hakim menilai gugatan tersebut bukan kategori gugatan sederhana karena nilai materiil gugatannya melebihi dari ketentuan Perma No.2 Tahun 2015 dan Perma No.4 Tahun 2019, selain itu gugatan yang diajukan penggugat merupakan sengketa hak atas tanah yang juga tidak sesuai dengan ketentuan Perma No.2 Tahun 2015 dan Perma No. 4 Tahun 2019".16

Berdasarkan hal-hal yag telah penulis uraikan di atas, menjadi penting bagi para pencari keadilan yang akan melakukan gugatan sederhana, terlebih dahulu memeriksa secara seksama syarat-syarat yang ditentukan berdasar ketentuan Pasal 3 dan Pasal 4 untuk memastikan apabila perkara yang akan dimasukkan sama pada kriteria perkara sederhana atau tidak menurut peraturan yang ada. Walaupun terhadap perkara tersebut penggugat dapat

\footnotetext{
${ }^{16}$ Wawancara dengan Timur Agung Nugroho,S.H, M.H, Hakim tunggal Perkara Gugatan Sedehana Pengadilan Negeri Selong, pada hari Selasa,11 Agustus Tahun 2020.
}

mengajukan/mendaftarkan

kembali gugatannya asalkan memenuhi syarat yang ditentukan peraturan yang ada dan/atau dapat diajukan kembali dalam bentuk gugatan biasa, akan tetapi tentu penggugat telah mengalami kerugian baik itu materiil mapun kerugian waktu.

\section{e. Penetapan Hari Sidang, Pemanggilan dan Kehadiran Para Pihak}

Berdasarkan ketentuan dalam Perma No. 2 Tahun 2015 dan Perma No. 4 Tahun 2019, setelah pemeriksaan pendahuluan selesai dilakukan dan hakim menilai gugatan sederhana tersebut dapat diperiksa dan diputus secara sederhana maka hakim menetapkan hari sidang pertama dan memerintahkan jurusita memanggil para pihak yang bersengketa untuk hadir dalam persidangan. Sebagaimana disebutkan pada Peraturan Mahkamah Agung No. 2 Tahun 2015 Pasal 12.

Selanjutnya, perihal kehadiran para pihak disebutkan dalam Pasal 13 Perma No. 4 Tahun 2019 berbunyi:

(1) Apabila penggugat tidak hadir pada hari sidang pertama tanpa alasan yang sah, maka gugatan dinyatakan gugur;

(2) Dalam hal tergugat tidak hadir pada hari sidang pertama, maka dilakukan pemanggilan kedua secara patut;

(3) Dalam hal tergugat tidak hadir pada hari sidang kedua setelah dipanggil secara patut maka Hakim memutus perkara secara verstek;

(4) Terhadap putusan sebagaimana dimaksud pada ayat (3), tergugat dapat mengajukan perlawanan (verzet) dalam tenggang waku 7 (tujuh) hari setelah pemberitahuan putusan;

(5) Dalam hal tergugat hadir pada sidang pertama dan pada hari sidang berikutnya tidak hadir tanpa alasan yang sah, maka gugatan diperiksa dan diputus secara contradiktoir,

(6) Terhadap putusan sebagaimana 
dimaksud pada ayat (3a) dan ayat (4), tergugat dapat mengajukan upaya hukum keberatan.

Berdasarkan Pasal 13 ayat (1) dan ayat (2) di atas, dapat dijelaskan bilamana penggugat yang tidak hadir pada hari sidang pertama setelah dipanggil secara patut maka gugatan akan digugurkan ayat (1), sedangkan bilamana tergugat yang tidak hadir pada hari sidang pertama setelah dilakukan pemanggilan secara patut maka akan dilakukan pemanggilan kedua. Secara umum Pasal 13 ini erat kaitannya dengan batas waktu penyelesaian gugatan sederhana menurut Pasal 5 ayat (3) maksimal paling lama 25 (dua puluh lima) hari kerja sejak hari sidang pertama.

Namun demikian, berdasarkan penelitian di Pengadilan Negeri Selong tidak selamanya penerapan Pasal 13 khususnya ayat (3) dan ayat (4) dapat terlaksana sesuai dengan harapan. Penerapan sering dipengaruhi keadaan para pihak saat persidangan berlangsung yang menjadi pertimbangan hakim. Ada 3 (tiga) perkara di Pengadilan Negeri Selong yang melebihi batas waktu 25 hari sesuai ketentuan dalam Pasal 5 ayat (2) Perma No. 2 Tahun 2015. Salah satu di antaranya adalah perkara gugatan sederhana klasifikasi wanprestasi yakni perkara No. 28/Pdt.GS/2019/PN SEL.

Menurut Timur Agung Nugroho, S.H, $\mathrm{M} . \mathrm{H}$, yang menjadi Hakim Tunggal perkara gugatan sederhana di Pengadilan Selong dalam penjelasannya, mengatakan : "Hal ini terjadi karena para pihak, dalam hal ini tergugat sering kali berhalangan tidak hadir pada sidang hari pertama. Selain itu pada tahap pemeriksaan alat bukti surat dan keterangan saksi, tergugat tidak hadir karena belum bisa menyediakan bukti-bukti tersebut. Pada saat hari sidang berikutnya tergugat hadir dan meminta penundaan waktu sidang untuk bukti dan keterangan saksi. Hal ini tentu menjadi pertimbangan bagi hakim dalam memperhatikan kepentingan para pihak, yang berkonsekuensinya tidak terlaksanannya dengan tepat ketentuan yang dimaksud Pasal 5 ayat (3) Perma No 2. Tahun 2015, termasuk Pasal 13 ayat (3), ayat (4) Perma No.4 Tahun 2019".17

Dari penjelasan Timur Agung Nugroho, S.H, M.H, tersebut dapat dikatakan belum ada perkara gugatan sederhana klasifikasi wanprestasi di Pengadilan Negeri Selong yang diputus secara verstek oleh hakim walaupun tergugat tidak memenuhi ketentuan dalam Pasal 13 ayat (3) dan ayat (4).

\section{f. Peran Hakim}

Pada persidangan perkara perdata biasa, hakim dalam penyelesaian perkara bersifat pasif, yang aktif dalam setiap persidangan adalah para pihak yang berperkara untuk membuktikan segala kepentingannya. Hakim sepenuhnya bersandar pada pembuktian yang diajukan oleh para pihak dan memberikan putusan berdasarkan pembuktian yang diperlihatkan, digunakan, dan dipertahankan (kebenaran formal) oleh para pihak.

\section{g. Pemeriksaan Sidang dan Perdamaian}

Dalam proses pemeriksaan perkara dalam persidangan terdapat beberapa hal yang membedakan gugatan sederhana dengan acara persidangan perkara biasa. Pada gugatan sederhana tidak dapat diajukan tuntutan provisi, eksepsi, rekonvensi, intervesi, replik, duplik, dan kesimpulan, sedangkan dalam perkara biasa semua itu dapat diajukan.

Hal ini sebagaimana dalam ketentuan Pasal 16 Perma No. 2 Tahun 2015 yang berbunyi: "Dalam proses pemeriksaan gugatan sederhana, tidak dapat diajukan tuntutan provisi, eksepsi, rekonvensi, utervensi, replik, duplik, atau kesimpulan". Atau dapat dikatakan proses pemeriksaan

\footnotetext{
${ }_{17}$ Wawancara dengan Timur Agung Nugroho,S.H, M.H, Hakim tunggal Perkara Gugatan Sederhana di Pengadilan Negeri Selong, pada hari Kamis tanggal 13 Agustus Tahun 2020
} 
gugatan sederhana hanya meliputi pembacaan gugatan, jawaban, pemeriksaan bukti surat dan meminta keterangan saksi yang diajukan oleh para pihak.

Seperti dikatakan sebelumnya bahwa dalam proses persidangan perkara gugatan sederhana, dijelaskan bahwa hakim bersifat aktif termasuk dalam upaya mendamaikan para pihak. Perdamaian dalam perkara gugatan sederhana diatur dalam Pasal 15 Perma No. 2 Tahun 2015:

(1) Pada hari sidang pertama, hakim wajib mengupayakan perdamaian, denga memperhatikan batas waktu sebagaimana dimaksud dalam Pasal 5 ayat (1);

(2) Upaya perdamaian dalam perma ini mengecualikan ketentuan yang diatur dalam ketentuan Mahkamah Agung mengenai prosedur mediasi;

(3) Dalam tercapai perdamaian, hakim membuat Putusan Akta Perdamaian yang mengikat para pihak;

(4) Terhadap Putusan Akta Perdamaian tidak dapat diajukan upaya hukum apapun;

(5) Dalam hal tercapai perdamian di luar persidangan dan perdamaian tersebut tidak dilaporkan kepada hakim, maka hakim tidak terikat dengan perdamaian tersebut.

Sedangkan ketentuan Pasal 16, dalam hal perdamaian tidak tercapai pada persidangan pertama, maka persidangan dilanjutkan dengan pembacaan gugatan, upaya hakim dalam mendamaikan kedua belah sejak mulai sidang hari pertama dan sidang pada hari-hari berikutnya. Bahkan menyarankan upaya perdamaian dapat dilakukan di luar persidangan yang bila tercapai melaporkan kepada hakim hasil perdamaian tersebut. Apabila hasil perdamian tidak dilaporkan kepada hakim, maka hakim tidak terikat dengan perdamaian yang konsueknsinya perdamaian itu tidak memiliki ketetapan pengadilan. Hasil perdamaian para pihak di dalam persidangan dan/atau di luar persidangan yang dilaporkan kepada hakim menjadi landasan atau dasar dikeluarkannya putusan hakim dalam bentuk Putusan Akta Perdamaian yang kekuatannya mengikat para pihak dan tidak bisa dilakukan upaya hukum apapun. Dalam perkara gugatan sederhana di Pengadilan Negeri Selong dari tahun 2016 s.d Juli 2020, ada sekitar 33 kasus yang berdamai.

Penerapan hakim berperan aktif dalam mendamaikan para pihak berperkara pada Pengadilan Negeri Selong dapat dilihat pada Tabel 1 di atas, Putusan Akta Perdamaian dari perkara gugatan sederhana klasifikasi wanprestasi paling banyak dibanding dengan putusan yang lainnya.

\section{h. Pembuktian}

Pembuktian dan pemeriksaan bukti-bukti dalam gugatan sederhana pada dasarnya sama dengan pembuktian dalam gugatan biasa. Bukti-bukti yang diperiksa meliputi bukti surat dan bukti keterangan saksi. Perbedaannya terletak pada alat bukti surat, pada perkara gugatan sederhana wajib diajukan bersamaan dalam gugatan pada saat pendaftaran gugatan, sedangkan dalam gugatan perkara perdata biasa keseluruhan bukti surat diajukan dalam sidang yang ditentukan waktunya untuk mengajukan dan pemeriksaan alat bukti.

Karena keriteria dan sifatnya yang sederhana maka pembuktian dalam perkara gugatan sederhana juga bersifat sederhana. Seperti pada ketentuan Pasal 6 ayat (4) Perma No.2 Tahun 2015 dan Perma No. 4 Tahun 2019 yang mewajibkan penggugat untuk melampirkan bukti surat pada saat pendaftaran gugatan untuk memastikan atau untuk dinilai dalam pemeriksaan pendahuluan apakah bukti-bukti yang diajukan penggugat sesuai atau tidak dengan ketentuan dalam Pasal 3 dan Pasal 4.

\section{i. Putusan dan Berita Acara Persidangan}

Penulis telah menguraikan di atas perihal batas waktu penyelesaian perkara gugatan sederhana menurut Pasal 5 ayat (3) Perma 
No. 2 Tahun 2015 paling lama 25 hari kerja sejak sidang pertama. Dengan kata lain, dalam waktu 25 hari kerja sejak hari sidang pertama proses persidangan perkara gugatan sederhana harus berakhir dan hakim memberi putusan. Terkait dengan putusan hakim terhadap perkara gugatan sederhana dapat dilihat dari waktu dikeluarkannya putusan hakim.

Pertama putusan hakim yang dikeluarkan sebelum ditetapkan jadwal sidang atau pada saat pemeriksaan pendahuluan yang disebut penetapan hakim sebagaimana dimaksud dalam Pasal 11 ayat (3) Perma No. 2 Tahun 2015. Apabila dalam pemeriksaan, Hakim berpendapat bahwa gugatan tidak termasuk dalam gugatan sederhana, maka Hakim mengeluarkan penetapan yang menyatakan bahwa gugatan bukan gugatan sederhana, mencoret dari register perkara dan memerintahkan pengembalian sisa biaya perkara kepada penggugat.

Kedua putusan hakim yang dikeluarkan pada saat pemeriksaan dan setelah pemeriksaan dalam sidang. Hal ini dapat dilihat dari:

(1) Putusan gugur, sebagaimana dalam Pasal 13 ayat (2) Perma No.4 Tahun 2019. Dalam penggugat tidak hadir pada hari sidang pertama tanpa alasan yang sah, maka gugatan dinyatakan gugur.

(2) Putusan Verstek, sebagaimana dalam Pasal 13 ayat (4) Perma No. 4 Tahun 2019. Dalam hal tergugat tidak hadir pada hari sidang kedua setelah dipanggil secara patut maka Hakim memutus perkara secara verstek.

(3) Putusan Contradiktoir, sebagaimana dalam Pasal 13 ayat (5) Perma No.4 Tahun 2019. Dalam hal tergugat hadir pada sidang pertama dan pada hari sidang berikutnya tidak hadir tanpa alasan yang sah, maka gugatan diperiksa dan diputus secara contradiktoir.

(4) Putusan Akta Perdamaian, sebagaimana dalam Pasal 15 Perma No.2 Tahun 2015. Dalam terwujudnya damai, majlis hakim memproduk Penetapan risalah damai yng mengikat para pihak.

Putusan perkara gugatan sederhana klasifikasi wanprestasi di Pengadilan Negeri Selong, berdasarkan tabel 2 dibawah ini, meliputi putusan sebagaimana dimaksud dalam Pasal 13 ayat (2), ayat (4), dan ayat (5) Perma No. 4 Tahun 2019 dan Pasal 15 Perma No. 2 Tahun 2015 yang telah diuraikan di atas, yang semuanya mengacu pada teknis beracara yang ditentukan dalam Pasal 19 Perma No.2 Tahun 2015:

(1) Hakim membacakan putusan dalam sidang terbuka untuk umum;

(2) Hakim wajib memberitahukan hak para pihak untuk mengajukan keberatan.

Selanjutnya dalam Pasal 20 ayat (2) dan ayat (3) Perma No.2 Tahun 2015 disebutkan: (1) $\ldots$

(2) dalam hal para pihak tidak hadir, jurusita menyampaikan pemberitahuan putusan paling lambat 2 (dua) hari setelah putusan diucapkan;

(3) atas permintaan para pihak salinan putusan diberikan paling lambat 2 (dua) hari setelah putusan diucapkan.

(5) Upaya Hukum dalam Gugatan Sederhana (Small Claim Court) di Pengadilan Negeri Selong.

Tabel 2 : Hasil Perkara/Putusan Gugatan Sederhana di PN Selong

\begin{tabular}{|c|c|c|c|}
\hline \multirow{2}{*}{ No } & \multirow{2}{*}{ Tahun } & \multicolumn{2}{|c|}{ Hasil Perkara/Putusan } \\
\hline & & Wanprestasi & $\mathrm{PMH}$ \\
\hline 1. & 2016 & $\begin{array}{l}1 \text { Kasus Putus } \\
\text { Dikabulkan }\end{array}$ & \\
\hline 2. & 2017 & $\begin{array}{l}\text { 1. Putus } \\
\text { Dikabulkan : } 1 \\
\text { kasus } \\
\text { 2. Damai : } 4 \text { kasus }\end{array}$ & \\
\hline 3. & 2018 & $\begin{array}{l}\text { 1. Damai : } 13 \\
\text { kasus } \\
\text { 2. Cabut : } 4 \text { kasus } \\
\text { 3. Penetapan } \\
\text { Dismissal/gugur } \\
: 2 \text { kasus } \\
\text { 4. Putus } \\
\text { Dikabulkan : } 2 \\
\text { kasus }\end{array}$ & $\begin{array}{l}\text { 1. Dicabut : } 2 \\
\text { kasus } \\
\text { 2. Damai : } 2 \\
\text { kasus }\end{array}$ \\
\hline 4. & 2019 & $\begin{array}{l}\text { 1. Damai : } 16 \\
\text { kasus } \\
\text { 2. Putus } \\
\text { Dikabulkan : } 6\end{array}$ & $\begin{array}{l}\text { 1. Damai : } 15 \\
\text { kasus } \\
\text { 2. Putus } \\
\text { Dikabulkan : }\end{array}$ \\
\hline
\end{tabular}




\begin{tabular}{|c|c|c|c|}
\hline & & $\begin{array}{l}\text { kasus } \\
\text { 3. Cabut : } 3 \text { kasus } \\
\text { 4. Penetapan } \\
\text { Dismissal/Gugur } \\
: 2 \text { kasus }\end{array}$ & $\begin{array}{l}7 \text { kasus } \\
\text { 3. Cabut : } 3 \\
\text { kasus } \\
\text { 4. Penetapan } \\
\text { Dismissal/gu } \\
\text { gur : } 1 \\
\text { kasus }\end{array}$ \\
\hline 5. & 2020 & $\begin{array}{l}\text { 1. Ditolak : } 1 \\
\text { kasus } \\
\text { 2. Dicabut : } 1 \\
\text { kasus } \\
\text { 3. Putus } \\
\text { Mengabulkan : } \\
3 \text { kasus } \\
\text { 4. Penetapan } \\
\text { Dismissal/Gugur } \\
: 1 \text { kasus }\end{array}$ & $\begin{array}{l}\text { 1. Damai : } 3 \\
\text { kasus } \\
\text { 2. Cabut : } 1 \\
\text { kasus }\end{array}$ \\
\hline \multicolumn{2}{|c|}{ Total } & 60 & 34 \\
\hline
\end{tabular}

Putusan hakim tidak selamanya diterima sebagai purtusan yang telah memberi dan memenuhi rasa keadilan bagi para pihak. Selain itu juga putusan hakim tidak selamanya luput dari kelalaian, kesalahan, kehilapan baik secara teknis beracara maupun terhadap materi yang digunakan atau diterapkan di dalam proses beracara sampai dihasilkannya putusan akhir persidangan. Atas dasar itu bagi para pihak yang keberatan terhadap putusan hakim dapat melakukan upaya hukum yang pengajuannya diatur berdasarkan peraturan perundang-undangan.

Upaya hukum pada perkara gugatan sederhana berbeda dengan upaya hukum pada perkara perdata biasa. Upaya hukum pada perkara biasa meliputi Verzet, Dendenverzet, Banding, Kasasi dan Peninjauan Kembali sedangkan upaya hukum pada perkara gugatan sederhana hanya meliputi verzet dan keberatan. Dalam ketentuan Pasal 13 ayat (3a) Perma No.2 Tahun 2015, "Terhadap putusan sebagaimana dimaksud ayat (3), tergugat dapat mengajukan perlawanan (verzet) dalam tenggang waktu 7 (tujuh) hari setelah pemberitahuan putusan". Selanjutnya dalam Pasal 21 ayat (1) menyebutkan: "Upaya hukum terhadap putusan gugatan sederhana sebagaimana dimaksud dalam Pasal 20 adalah dengan mengajukan keberatan".
Dengan demikian, upaya hukum yang disediakan dan dapat ditempuh oleh para pihak dalam gugatan sederhana hanya berupa permohonan perlawanan/verzet dan permohonan keberatan, Tergugat yang akan mengajukan perlawanan (verzet) harus dalam waktu 7 (tujuh) setelah pemberitahuan putusan, melebihi waktu tersebut maka tidak bisa diajukan verzet. Terhadap putusan verzet dapat dilakukan keberatan (Pasal 13 ayat (3a) dan ayat (5).

\section{j. Permohonan dan Pemberitahuan Keberatan}

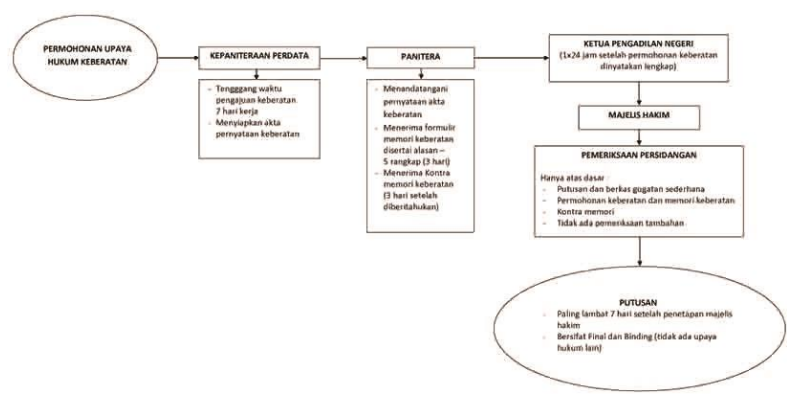

Gambar 2 : Alur Upaya Hukum Keberatan

Pada Pasal 22 Perma No. 2 Tahun 2015 disebutkan bahwa permohonan keberatan diajukan paling lambat 7 (tujuh) hari setelah putusan diucapkan atau setelah pemberitahuan putusan, kepada Ketua Pengadilan dengan mengisi blanko permohonan keberatan yang disediakan di kepaniteraan. Jika permohonan yang diajukan melampaui batas waktu pengajuan yakni melebihi 7 (tujuh) hari, maka permohonan keberatan dinyatakan tidak dapat diterima dengan penetapan ketua pengadilan berdasarkan surat keterangan panitera.

Selanjutnya dalam Pasal 23 Perma No.2 Tahun 2015 dijelaskan bagian kepaniteraan perdata menerima dan memeriksa kelengkapan berkas permohonan keberatan yang disertai dengan memori keberatan pemohon. Sedangkan termohon menyertakan kontra memori keberatan yang diajukan kepada Ketua Pengadilan. Setelah permohonan yang disertai memori keberatan 
diajukan oleh pemohon dalam waktu 3 (tiga) keberatan tersebut disampaikan kepada termohon keberatan. Atas pemberitahuan permohonan keberatan tersebut, termohon dalam waktu 3 (tiga) hari menyampaikan kontra memori kepada pengadilan.

\section{k. Pemeriksaan Keberatan}

Pada uraian sebelumya, penulis mengutip dalam bimbingan Teknis Penyelesaian Perkara Gugatan Sederhana Direktoral Jenderal Badan Peradilan Umum Mahkamah agung Republik Indonesia Tahun 2015 yang menjelaskan bahwa perkara gugatan sederhana diperiksa dan diputus dalam 2 (dua) tingkatan oleh pengadilan negeri yang sama. Tingkat pertama, perkara diperiksa dan diputus oleh hakim tunggal dengan ketentuan dalam Pasal 1 ayat (3) Perma No. 4 Tahun 2019. Sedangkan pada tingkat upaya hukum keberatan diperiksa dan diputus oleh majelis hakim.

Ketentuan perihal pemeriksaan keberatan dalam perkara gugatan sederhana diatur dalam Pasal 25 dan Pasal 26 Perma No.2 Tahun 2015 sebagai berikut. Pasal 25 berbunyi:

(1) Ketua pengadilan menetapkan Majelis Hakim untuk memeriksa dan memutus permohonan keberatan, paling lambat 1 (satu) hari setelah permohonan dinyatakan lengkap;

(2) Pemeriksaan keberatan dilakukan oleh Majelis Hakim yang dipimpin oleh Hakim senior yang ditunjuk oleh Ketua Pengadilan.

dan Pasal 26 :

(1) Segera setelah ditetapkannya Majelis Hakim, dilakukan pemeriksaan keberatan;

(2) Pemeriksaan keberatan dilakukan hanya atas dasar :

a. putusan dan berkas gugatan sederhana;

b. permohonan keberatan dan memori keberatan; dan

c. kontra memori keberatan;
(3) Dalam pemeriksaan keberatan tidak lakukan pemeriksaan tambahan.

Berdasarkan ketentuan dalam Pasal 25 ayat (2) dan Pasal 26 ayat (1) di atas, perkara gugatan sederhana diperiksa dan diputus oleh majelis hakim dan bukan oleh hakim tunggal. Hal lain, yang dinilai dalam pemeriksaan keberatan hanya putusan dan berkas gugatan sederhana, memori keberatan, dan kontra memori keberatan. Tidak ada pemeriksaan tambahan dalam pemeriksaan upaya hukum keberatan, hal ini berbeda dengan upaya hukum banding dan kasasi pada perkara perdata biasa, dalam perihal tertentu hakim banding dan kasasi dapat memerintahkan dilakukan pemeriksaan ulang.

\section{Putusan Keberatan}

Permohonan keberatan yang diajukan oleh pemohon keberatan harus diselesaiakan dalam waktu 7 (tujuh) hari dan putusan hakim tidak dapat diajukan upaya hukum apapun. Artinya putusan keberatan memiliki kekuatan hukum dan final (inkrah) mengikat kedua belah pihak sejak putusan oleh hakim diberitahukan 3 (tiga) hari setelah putusan dibacakan. Selain itu upaya hukum lanjutan dari para pihak sudah tertutup untuk diajukan.

Ketentuan dalam Pasal 27 Perma No.2 Tahun 2015 meyebutkan : "Putusan terhadap permohonan keberatan diucapkan paling lambat 7 (tujuh) hari setelah tanggal penetapan Majelis Hakim".

Selanjutnya Pasal 29 menyebutkan bahwa:

1) Pemberitahuan putusan keberatan disampaikan kepada para pihak paling lambat 3 (tiga) hari sejak diucapkan

2) putusan keberatan berkekuatan hukum tetap terhitung sejak disampaikannya pemberitahuan. Mengenai putusan keberatan merupakan putusan akhir gugatan sederahan disebutkan dalam asal 30 yakni keberatan merupakan putusan akhir yang tidak tersedia upaya 
hukum banding, kasasi atau peninjauan kembali.

Penerapan pemerikasaan keberatan terhadap perkara gugatan sederhana khususnya klasifikasi wanprestasi yang diajukan para pemohon di lingkungan Pengadilan Negeri Selong dapat dilihat pada Tabel 5 di atas. Dari 56 jumlah perkara gugatan sederhana klasifikasi wanprestasi tersebut hanya ada 3 (tiga) perkara yang diajukan permohonan keberatan, yakni perkara No. 8/Pdt.GS/2020/PN SEL, Perkara No.9/Pdt.GS/2020/PN SEL, dan Perkara No.10/Pdt.GS/2020/PN SEL.

Dari Tabel 2 di atas, dapat dikatakan para pihak dalam perkara gugatan sederhana lebih banyak yang menerima hasil putusan hakim dan sedikit sekali yang menolak putusan dengan mengajukan upaya hukum keberatan terhadap putusan hakim tersebut. Hal ini terlihat juga dengan putusan berdasarkan Putusan Akta Perdamaian para pihak yang paling banyak di banding dengan putusan dalam bentuk yang lain. Jikalaupun ada putusan hakim pada pemeriksaan pendahuluan dan putusan digugurkan (dismissal) jumlahnya sangat sedikit.

\section{Pelaksanaan Putusan Gugatan Sederhana di PN Selong}

Secara umum pelaksanaan suatu putusan dilakukan setelah putusan berkekuatan hukum tetap, hal ini berlaku pada semua jenis perkara baik itu perkara perdata biasa maupun perkara sengketa sederhana. Ketentuan dalam Pasal 31 ayat (1) Perma No.2 Tahun 2015 menyebutkan: "Untuk penetapan sebagaimana dimaksud dalam Pasal 20 yang tidak diajukan keberatan sebagaimana dimaksud pada Pasal 22 ayat (1), maka putusan berkekuatan hukum tetap".

Semangat yang dikedepankan Perma No. 2 Tahun 2015 dan Perma No. 4 Tahun 2019 adalah bagaimana penyelesaian perkara secara sederhana, cepat, dan biaya ringan. Perihal tersebut telah penulis jelaskan pada uraian-uraian sebelumnya yang pada intinya proses berperkara dalam gugatan sederhana sangat membantu para pencari keadilan dalam mengajukan persoalan dan kepentingannya.

Dalam wawancara penulis dengan Zainul Fikri, SH, salah satu advokat yang sering mendampingi perkara gugatan sederhana klasifiasi wanprestasi menyatakan bahwa, "Gugatan sederhana merupakan wadah yang efektif bagi pencari keadilan, terutama para kreditur baik perbankkan maupun perorangan. Bisa dibayangkan apabila nilai materiil perjanjian mereka dengan debitur hanya di bawah Rp. 50.000.000 (lima puluh juta) misalnya kemudian mereka harus melalui proses pengadilan perkara perdata biasa, maka waktu dan biaya yang dikeluarkan tidak sebanding dengan nilai gugatan. Lebih lebih setelah terbitnya Perma No.4 Tahun 2019 sebagai perubahan Perma No.2 Tahun 2015, khususnya perihal nilai materiil gugatan yang semula maksimal $R p$. 200.000.000 (dua ratus juta) menjadi $R p$. 500.000 .000 (lima ratus juta) sangat membantu para kreditur".18

Dalam wawancara penulis dengan Sarindawan, SE, Direktur PD.BPR NTB Lombok Timur, yang sering mengajukan gugatan sederhana klasifikasi wanprestasi juga mengatakan: "... Kami dari pihak bank sangat terbantu terhadap masalah wanprestasi yang dilakukan oleh para debitur atau nasabah kami yang tidak melakukan kewajibannya".19

Berdasarkan hasil wawancara tersebut di atas, perkara yang diajukan melalui gugatan sederhana pada dasarnya sangat membantu para pihak khususya kreditur untuk menemukan jalan keluar atas terjadinya tindakan PMH dan wanprestasi. Namun demikian, bukan berarti tidak ada

${ }^{18}$ Wawancara dengan Zainul Fikri, SH, Advokat pada Kantor BM\&Patners, Advokate\&Legal Consultant, pada hari Jumat, tanggal 7 Agustus Tahun 2020.

${ }^{19}$ Wawancara dengan Sarindawan, SE, Direktur PD.BPR NTB Lombok Timur, Selasa, tanggal 11 Agustus Tahun 2020. 
permasalahan setelah putusan hakim berkekuatan hukum tetap.

Petunjuk dan pedoman pelaksanaan terhadap putusan yang telah berkekuatan hukum tetap dapat dilihat dalam ketentuan Pasal 31 ayat (2) dan ayat (3) Perma No.2 Tahun 2015 bahwa Penetapan yang telah inkracht dilaksanakan secara sukarela, Dalam hal ketentuan pada ayat (2) tidak dipatuhi, maka putusan dilaksanakan berdasarkan ketentuan hukum acara perdata yang berlaku.

Aturan dalam Pasal 31 ayat (2) di atas dapat penulis dikatakan bahwa pelaksanaan putusan hakim bersandarkan pada kesukarelaan para pihak dalam ini sukarela dari pihak yang dikalahkan. Karena mengukur kesadaran dan kemauan tidak dapat dilakukan dengan cara matematis, dalam hal ini ukurannya adalah apabila pihak yang kalah sadar dan mau tunduk pada putusan, maka pelaksanaan/eksekusi putusan dapat dilaksanakan. Dan sebaliknya apabila pihak yang kalah tidak tunduk pada putusan, maka pelaksanaan/eksekusi tidak dapat dilaksanakan.

Julius Bolla Panitera Pengadilan Negeri Selong menjelaskan perihal Pelaksanaan Putusan secara sukarela dengan menagatakan, "atas kesadaran dan kemauan sendiri pihak Terguga / Pihak yang kalah memenuhi bunyi isi putusan tanpa paksaan dan Pelaksanaan putusan berdasarkan hokum acara Perdata yang berlaku artinya pelaksanaan putusan seperti dalam gugatan biasa". ${ }^{20}$

Begitu juga dengan ketentuan dalam Pasal 31 ayat (3) yang megembalikan pelaksanaan putusan menurut proses pelaksanaan putusan perkara perdata biasa sebagai alternatif jika pelasakanaan putusan secara sukarela tidak dapat terlaksana. Ketentuan ini seperti bertolak belakang dari tujuan awal dari Perma No.2 Tahun 2015 dan

\footnotetext{
20Wawancara dengan Julius Bolla, Ketua Panitera Pengadilan Negeri Selong pada hari Rabu, tanggal 5 Agustus Tahun 2020.
}

Perma No. 4 Tahun 2019 yang menginginkan tercapainya beracara di pengadilan dengan sederhana, cepat, dan biaya ringan. Karena pelaksanaan putusan berdasarkan Pasal 22 ayat (3) memerlukan proses permohonan eksekusi dari pihak yang dimenangkan dalam putusan kepada pengadilan, yang umum diketahui secara bersama hal tersebut memerlukan tambahan biaya dan waktu.

Dalam wawancara penulis dengan Zainul Fikri, SH dan Sarindawan,SE., hal tersebut terungkap bahwa kelemahan dalam perkara gugatan sederhana ini adalah pelaksanaan putusan/pelaksanaan eksekusi. Dikatakan pihak yang dimenangkan tidak bisa langsung mengeksekusi putusan melainkan terlebih dahulu harus bermusyawarah ulang dengan pihak yang kalah. Jikalau mereka para debitur atau pihak yang kalah secara sukarela menerima maka tidak jarang kedua belah pihak secara bersama-sama menjual jaminan misalnya untuk melunasi tonggakan debitur. Persoalan muncul manakala mereka tidak menerima putusan, maka perlu melakukan annmaming dan kadang mengajukan permohonan eksekusi kepada pengadilan. ${ }^{21}$

\section{Efektifitas Gugatan Sederhana dalam Penyelesaian Perkara Wanprestasi di PN Selong}

Perkara gugatan sederhana yang disengketakan di Pegadilan Negeri Selong sejak diberlakukannya Perma No. 2 Tahun 2015 dan Perma No. 4 Tahun 2019 sampai dengan bulan Juli Tahun 2020 sebanyak 94 perkara. Berdasarkan Tabel 1, jumlah gugatan sederhana klasifikasi wanprestasi sejumlah 60 perkara, dan gugatan sederhana klasifikasi PMH sejumlah 34 perkara (Tabel 1). Apabila dilihat dari jumlah perkara barangkali akan dinilai jumlah tersebut masih kecil, akan tetapi jika dilihat dari peningkatan jumlah dari tahun ke tahun dapat dikatakan

${ }^{21}$ Wawancara dengan Zainul Fikri, S.H, Advokat pada Kantor BM\&Patners, Advokate\&Legal Consultant, Jumat 7 Agustus 2020 dan Sarindawan, Direktur PD.BPR NTB Lombok Timur, pada hari Selasa tanggal 11 Agustus Tahun 2020 
penyelesaian sengketa melalui gugatan sederhana mengalami peningkatan dari tahun ke tahun.

Dengan demikian, secara umum dapat dikatakan keberadaan Perma No. 2 Tahun 2015 dan Perma No. 4 Tahun 2019 sebagai pedoman hakim dalam penyelesaian perkara gugatan sederhana klasifikasi wanprestasi yang diajukan di Pegadilan Negeri Selong sangat efektif. Hal ini sejalan dengan tujuan dari pradilan yang berdasarkan asas sederhana, cepat dan biaya ringan. Sedangkan untuk melihat efektivitas secara khusus mengenai keberlakuan Perma No.2 Tahun 2015 dan Perma No.4 Tahun 2019 dapat dilihat atau dapat diukur dari beberapa aspek yang meliputi aspek kriteria perkara, aspek tahapan penyelesaian perkara, aspek batas waktu penyelesaian perkara dan aspek upaya hkum yang ditempuh para pihak. Beberapa aspek tersebut, dapat penulis paparkan sebagai berikut:

\section{a. Aspek Kriteria Perkara.}

Sebelum diuraikan lebih lanjut mengenai aspek kriteria perkara, penulis terlebih dahulu menyajikan jumlah perkara gugatan sederhana klasifikasi wanprestasi dan $\mathrm{PMH}$ yang telah diajukan di Pengadilan Negeri Selong dalam bentuk Tabel 1 di atas.

Ketentuan dalam Pasal 3 ayat (1) Perma No.2 Tahun 2015 menyatakan bahwa gugatan sederhana diajukan terhadap perkara cidera janji dan/PMH dengan nilai gugatan materil paling banyak Rp. 200.000.000 (dua ratus juta rupiah). Ketentuan tersebut telah dirubah dengan Perma No. 4 Tahun 2019, yang di dalam Pasal 3 ayat (1) Perma perubahan tersebut dikatakan bahwa gugatan sederhana diajukan terhadap perkara cidera janji dan/atau PMH dengan nilai gugatan materil paling banyak Rp. 500.000.000 (lima ratus juta ribu rupiah).

Dari ketentuan tersebut terdapat dua kriteria perkara gugatan sederhana yakni wanprestasi dan PMH. Sedangkan perkara gugatan sederhana yang diajukan di Pengadilan Negeri Selong sebagaimana disajikan pada Tabel 2 di atas, diperiksa dan diputus adalah gugatan sederhana klasifikasi wanprestasi dan PMH. Dengan kata lain, perkara-perkara gugatan sederhana yang diajukan di Pengadilan Negeri Selong telah sesuai dengan ketentuan sebagaimana yang dimaksud dalam Pasal 3 ayat (1) Perma No.2 Tahun 2015 dan Perma No. 4 Tahun 2019.

\section{b. Aspek Tahapan Penyelesaian.}

Tahapan penyelesaian perkara gugatan sederhana berdasarka Perma No. 2 Tahun 2015 dan Perma No. 4 Tahun 2019 meliputi: 1) pendaftaran; 2) pemeriksaan kelengkapan; 3) penetapan hakim dan penunjukan panitera pengganti; 4) pemeriksaan pendahuluan; 5) penetapan hari sidang dan pemanggilan para pihak; 6) pemeriksaan sidang dan perdamaian; dan 7) pembuktian dan putusan. Penerapan pelaksanaan di Pengadilan Negeri Selong berdasarkan tahapan-tahapan tersebut dengan berpedoman pada kesederhanaan sesuai dengan asas sederhana, cepat dan biaya ringan yang menjadi hal yang utama.

Efektifitas penerapan Perma No. 2 dan Perma No. 4 Tahun 2019 dalam semua tahapan penyelesaian perkara gugatan sederhana klasifikasi wanprestasi di Pengadilan Negeri Selong dapat dilihat dari Tabel 2 di atas. Penulis dapat menjelaskan sebagai berikut:

Pertama pada tahapan proses pemeriksaan berkas pendaftaran gugatan oleh penitera dengan menerapkan ketentuan dalam Pasal 7 Perma No.2 Tahun 2015, terdapat 6 (enam) perkara yang dicabut karena tidak memenuhi ketentuan Pasal 3 dan Pasal 4.

Kedua pada tahapan pemeriksaan pendahuluan terdapat 4 (empat) perkara gugatan sederhana yang digugurkan (dismissal) oleh hakim, dikarenakan juga tidak memenuhi ketentuan Pasal 3 dan Pasal 4. Dalam hal ini selain memberikan 
kesempatan kepada penggugat untuk memperbaiki gugatan dan mendaftarkan ulang, juga memberikan keringanan secara materiil dan waktu kepada penggugat untuk tidak menunggu, mengikuti/melanjutkan perkara ke tahap persidangan berikutnya, yang barangkali putusan dan/atau penetapan hakim sama dengan putusan da/atau penetapan pada pemeriksaan pendahuluan.

Ketiga , dan yang paling penting adalah putusan perdamaian pada tahapan pemeriksaan, putusan perdamian jumlahnya paling banyak dibandingkan dengan putusan yang lainnya. Penulis katakan paling penting karena putusan perdamaian dalam bentuk Putusan Akta Perdamaian secara substansi terlahir dari kesadaran para pihak yang berperkara untuk berdamai dan sama-sama diuntungkan dari hasil perdamaian dan secara proses hukum acara Penetapan Akta Perdamaian merupakan putusan final, berkekuatan hukum tetap, dan mengikat para pihak, serta tidak dapat dilakukan upaya hukum apapun bagi para pihak.

\section{Aspek Limitasi Batas Waktu Penyelesaian.}

Dalam Pasal 5 ayat (3) Perma No. 2 Tahun 2015 dan Perma No. 4 Tahun 2019 menyebutkan bahwa penyelesaian gugatan sederhana paling lama 25 (dua puluh lima) hari kerja sejak hari sidang pertama. Dan apabila berlanjut sampai pada tahapan penyelesaian gugatan sederhana keputusan keberatan, harus selesai dalam waktu tidak melebih dari 25 hari kerja sejak perkara gugatan sederhana didaftarkan.

Asas sederhana, cepat dan biaya ringan yang menjadi dasar penyelesaian tercermin dari adanya pembatasan waktu berperkara (Pasal 5). Walaupun demikian, dengan kondisi lingkungan dan pertimbangan hakim yang berbeda satu sama lain, penerapan ketentuan Pasal 5 tidak sepenuhnya dapat terlaksana. Pada penerapannya di Pengadilan Negeri Selong terdapat 1 (satu) perkara gugatan sederhana klasifikasi wanprestasi yakni perkara No.28/Pdt.GS/2019/PN SEL yang melewati batasan waktu 25 hari. Pertimbangan hakim dalam perkara tersebut adalah tergugat tidak hadir dalam hari sidang pertama dan tergugat tidak dapat mendatangkan saksi pada hari sidang yang ditentukan dan meminta diberikan kesempatan menghadirkan saksi pada hari sidang berikutnya.

\section{d. Upaya Hukum Lanjutan.}

Upaya hukum dalam gugatan sederhana berupa keberatan atas putusan hakim, dan tidak tersedia upaya hukum lainnya. Ketentuan ini berdasarkan Pasal 21 Perma No. 2 Tahun 2015 yang menyebutkan bahwa upaya hukum terhadap putusan gugatan sederhana adalah dengan mengajukan keberatan. Selanjutnya Pasal 30 disebutkan bahwa keberatan merupakan putusan akhir yang tidak tersedia upaya hukum banding, kasasi atau peninjauan kembali. Dari ketentuan Pasal 21 dan Pasal 30 tersebut terdapat hanya satu upaya hukum dalam perkara gugatan sederhana dan putusannya merupakan putusan akhir.

Sedangkan waktu pengajuan, pemeriksaan dan sampai putusan juga sangat terbatas sebagaimana ketentuan dalam Pasal 25 ayat (3) yang menyebutkan, ketua pengadilan menetapkan Majelis Hakim untuk memeriksa dan memutus permohonan keberatan, paling lambat 1 (satu) hari setelah permohonan dinyatakan lengkap. Selanjutnya dalam Pasal 27 menyebutkan bahwa putusan terhadap permohonan keberatan diucapkan paling lambat 7 (tujuh) hari setelah tanggal penetapan Majelis Hakim.

Berdasarkan pasal-pasal di atas dan bila dihubungkan dengan ketentuan dalam pasalpasal sebelumnya seperti Pasal 14 perihal hakim harus berperan aktif dan Pasal 15 perihal peran aktif hakim dalam upaya mendamaikan para pihak. Hakim menjelaskan kepada para pihak (penggugat dan tergugat) terkait dengan petingnya tercapainya perdamian, dan upaya hukum 
yang dapat ditempuh oleh para pihak. Perkara gugatan sederhana di Pengadilan Negeri Selong hanya terdapat 2 (dua) perkara yang diajukan upaya hukum keberatan. Hal ini tentu tidak lepas dari upaya hakim dan para pihak dalam berperkara untuk tercapainya perdamian.

\section{Kendala yang Dihadapi Sistem Gugatan Sederhana dalam Penyelesaian Perkara Wanprestasi di Pengadilan Negeri Selong.}

Sejak diberlakukannya Perma No. 2 Tahun 2015 dan Perma No. 4 Tahun 2019 dan sejak diterapkan oleh Pengadilan Negeri Selong telah memberikan kemudahan bagi para pihak dan dinilai cukup efektif dalam menyelesaikan persoalan yang dihadapi oleh para pihak, khususnya penggugat. Namun di samping ada kemudahan dan cukup efektif, dalam semua hal pasti akan selalu ada kendala-kendala, hambatan, dan rintangan. Beberapa kendala atau hambatan dalam pelaksanaan ketentuan Perma No. 2 dan Perma No. 4 Tahun 2019, sebagai berikut:

\section{a. Faktor Kesiapan Tergugat.}

Proses penyelesaian perkara gugatan sederhana menurut ketentuan Pasal 5 ayat (3) Perma No. 2 Tahun 2015 dan Perma No. 4 Tahun 2019 paling lama 25 (dua puluh lima) hari kerja sejak sidang hari pertama. Dalam pelaksanaannya di Pengadilan Negeri Selong masih terdapat perkara yang melebihi waktu 25 hari kerja, yakni perkara No. 28/Pdt.GS/2019/PN.SEL. Dalam proses penyelesaian perkara tersebut melebihi batas waktu 25 hari yang disebabkan oleh kesiapan tergugat dalam menjalani persidangan. Bapak Timur Agung Nugroho, S.H, M.H, salah seorang Hakim Tunggal perkara gugatan sederhana di Pengadilan Selong mengungkapkan: "Hal ini terjadi karena para pihak, dalam hal ini tergugat sering kali berhalangan tidak hadir pada sidang hari pertama. Selain itu pada tahap pemeriksaan alat bukti surat dan keterangan saksi, tergugat tidak hadir karena belum bisa menyediakan bukti-bukti tersebut. Pada saat hari sidang berikutnya tergugat hadir dan meminta penundaan waktu sidang untuk bukti dan keterangan saksi. Hal ini tentu menjadi pertimbangan bagi hakim dalam memperhatikan kepentingan para pihak, yang berkonsekuensi pada tidak terlaksanannya dengan tepat ketentuan yang dimaksud Pasal 5 ayat (3) Perma No 2. Tahun 2015, termasuk Pasal 13 ayat (3), ayat (4) Perma No.4 Tahun 2019. "22

Dari penjelasan Timur Agung Nugroho, S.H., M.H di atas, keterlambatan tersebut lebih disebabkan oleh kesiapan tergugat dalam menghadiri persidangan baik pada hari pertama sidang maupun sidang-sidang dengan agenda pemeriksaan bukti surat dan keterangan saksi. Meskipun pada dasarya dalam Pasal 13 ayat (3) dan ayat (4) Perma No. 4 Tahun 2019 memberikan pedoman kepada hakim untuk memutus perkara secara verstek dan/atau putusan contradictoir, akan tetapi hakim tidak melakukannya.

\section{b. Alamat atau Domisili Para Pihak}

Menurut ketentuan Pasal 4 ayat (3) Perma No. 2 Tahun 2015 dan Perma No. 4 Tahun 2019 bahwa domisili penggugat dan tergugat harus berada di daerah hukum pengadilan yang sama. Dalam praktiknya penggugat terkadang ragu untuk menentukan alamat tergugat yang bisa saja berubah sesuai dengan alamat awal tergugat yang diketahui oleh penggugat, tergugat bisa saja menghindari gugatan dengan cara meghindar atau pindah alamat. Hal demikian berakibat pada perubahan gugatan yang diajukan oleh penggugat.

Zainul Fikri, SH, kuasa hukum Tergugat kasus Nomor 3/Pdt.G.S/2020/PN.Sel mengatakan : "Tergugat II dalam Perkara Nomor 3/Pdt.G.S/2020/PN.Sel pada awalnya beralamat di rumahnya yakni di Lombok Timur, dan pada saat penggugat mengajukan

\footnotetext{
${ }^{22}$ Wawancara dengan Bapak Timur Agung Nugroho,S.H, M.H, Hakim tunggal Perkara Gugatan Sedehana Pengadilan Negeri Selong, pada hari kamis tanggal 13 Agustus Tahun 2020
} 
gugatan, dia mengatakan dirinya beralamat di Mataram, sehingga kami selaku penggugat mencabut gugatan. Walaupun hal tersebut dapat terselesaiakan, namun secara waktu dan biaya kami mengalami kerugian". ${ }^{23}$

Selain itu, ketentuan dalam Pasal 4 ayat (4) yang menyebutkan bahwa para pihak wajib mengadiri setiap hari persidangan meskipun sudah memberikan/mewakilkan kepada kuasa. Hal ini tentu sangat merugikan bagi penggugat yang berada tidak saja berbeda secara wilayah hukum akan tetapi berbeda tempat tinggal (berbeda pulau, atau berbeda provinsi).

Dalam perkara Nomor: 52/Pdt.G.S/2019/PN.Sel, penggugat diketahui beralamat di Jakarta Barat dan memberikan kuasa kepada "ASSUHANDI,SH \& REKAN" ADVOKAT/PEGACARA \& KONSULTAS HUKUM. Dalam proses persidangan berdasarakan Pasal 4 ayat (4), tergugat harus selalu hadir dalam setiap persidangan meskipun sudah memberikan kuasa. Faktanya, penggugat tidak pernah dapat menghadiri setiap persidangan sehingga terkendala bagi hakim untuk menerapkan upaya perdamaian di hari pertama persidangan.

Kuasa hukum tergugat Perkara Nomor: 52/Pdt.G.S/2019/PN.Sel, Zainul Fikri, SH mengatakan : "Penggugat tidak pernah menghadiri secara langsung setiap persidangan, tepatnya sampai tiga kali persidangan penggugat tidak pernah hadir. Dan selanjutnya kami pihak tergugat tidak mengetahui apakah Penggugat mencabut gugatannya atau tidak, karena selanjutnya tidak ada panggilan sidang ataupun pemberitahuan lainnya". 24

Hal tersebut diperjelas oleh Julius Bolla, Panitera Pengadilan Negeri Selong yang mengatakan : "Memang benar, Perkara Nomor: 52/Pdt.G.S/2019/PN.Sel, penggugat berasal dari Jakarta Barat yang wilayah

\footnotetext{
${ }^{23}$ Wawancara dengan Bapak Zainul Fikri, Kuasa Hukum Perkara3/Pdt.G.S/2020/PN.Sel pada hari, Jumat 7 Agustus 2020.

${ }^{24}$ lbid
}

hukumnya berbeda dengan tergugat, sehingga menggunakan kuasa advokat yang beralamat sama dengan tergugat di wilayah hukum Pegadilan Negeri Selong. Tetapi dalam setiap persidangan pengggugat tidak pernah menghadiri persidangan sebagaimana diwajibkan ketentuan Pasal 2 ayat (4), sehingga upaya perdamaian pada sidang hari pertama tidak dapat dilakukan. Perkara tersebut oleh hakim digugurkan".25

Berdasarkan uraian di atas, ketentuan yang mengharuskan penggugat berada dalam wilayah hukum yang sama dengan tergugat menjadi halangan tersendiri bagi pengggugat baik dalam menentukan alamat tergugat dalam gugatannya yang sewaktuwaktu tergugat berpindah-pindah alamat. Selain itu, ketentuan yang mengharuskan penggugat hadir dalam setiap persidangan memberatkan bagi penggugat. Selain penggugat sudah mengeluarkan biaya untuk kuasa hukum, penggugat juga harus mengeluarkan biaya utuk menghadiri setiap persidangan.

\section{c. Pelaksanaan Putusan}

Ketentuan dalam Pasal 31 ayat (2) menyebutkan bahwa pelaksanaan putusan hakim dijalankan secara sukarela. Apabila pihak yang kalah sadar dan mau tunduk pada putusan, maka pelaksanaan/eksekusi putusan dapat dijalankan. Dan sebaliknya apabila pihak yang kalah tidak tunduk pada putusan, maka pelaksanaan/eksekusi tidak dapat dijalankan. Begitu juga dengan ketentuan dalam Pasal 31 ayat (3) yang megembalikan pelaksanaan putusan menurut proses pelaksanaan putusan perkara perdata biasa sebagai alternatif jika pelaksanaan putusan secara sukarela tidak dapat dijalankan.

Perkara-perkara gugatan sederhana yang diselesaikan di Pengadilan Negeri Selong, beberapa di antaranya tidak dapat dijalankan sebagaimana ketentuan yang ada. Salah satu

25 Wawancara dengan Bapak Julius Bolla Panitera Pengadilan Negeri Selong pada hari Rabu, 5 AgustusTahun 2020. 
perkara yang pelaksanaan putusan tidak dapat berjalan sebagaimana mestinya yakni Perkara dengan Nomor 18/Pdt.G.S/2018/PN.Sel antara PT. Bank Perkreditan Rakyat Segara Anak Kencana sebagi Penggugat dan Amaq Sahdan, dkk sebagai Tergugat.

Zainul Fikri, SH, kuasa hukum PT. Bank Perkreditan Rakyat Segara Anak Kencana selaku penggugat menjelaskan : "Sengketa Nomor 18/Pdt.G.S/2018/PN.Sel yang diputus dalam bentuk Putusan Akta Perdamaian, pada hari kamis, tanggal 20 Desember 2018 walaupun Tergugat yakni Amaq Sahdan, dkk dinyatakan telah wanprestasi dan menyerahkan jaminan untuk dijual oleh Bank selaku Penggugat secara bersama-sama, tapi sampai dalam pelaksanaanya Tergugat berdalih dengan berbagai alasan. ".26

Berdasarkan uraian di atas, dapat dikatakan bahwa pelaksanaan putusan atas dasar ketentuan Pasal 31 ayat (2) seperti ini bertolak belakang dari tujuan Perma No. 2 Tahun 2015 dan Perma No. 4 Tahun 2019 yang menginginkan tercapainya proses beracara di pengadilan dengan cepat, sederhana, dan biaya ringan. Karena pelaksanaan putusan berdasarkan Pasal 31 ayat (3) memerlukan proses permohonan eksekusi dari pihak yang dimenangkan dalam putusan, yang umum juga diketahui secara bersama hal tersebut memerlukan tambahan biaya dan waktu.

Hal tersebut diperjelas oleh Julius Bolla, Panitera Pengadilan Negeri Selong yang mengatakan : "Memang benar, kendala yang kita hadapi dalam pelaksanaan hasil putusan gugatan sederhana yang sudah mempunyai kekuatan hukum tetap (masalah eksekusi) belumdiaturkhususdalamPerma No. 2 Tahun 2015 dan Perma No. 4 Tahun 2019, sehingga kita di Pengadilan Negeri Selong masih mengacu kepada pelaksanaan eksekusi terhadap hasil putusan gugatan biasa atau yang sesuai pada Hukum Acara Perdata biasa. ${ }^{27}$

\section{KESIMPULAN}

Penyelesaian perkara perdata melalui gugatan sederhana di Pengadilan Negeri Selong sangat membantu masyarakat untuk menyelesaikan perkaranya dengan cara sederhana, cepat, dan biaya ringan. Perma No. 2 Tahun 2015 dan Perma No. 4 Tahun 2019 menjadi terobosan baru dan mengisi kekosongan hukum untuk menyelesaikan perkara-perkara sederhana yang sebelumnya diselesaikan secara biasa. Gugatan sederhana bersifat limitative mengartikan jika salah satu syarat yang telah ditentukan tidak dipenuhi makaperkara tersebut tidakdapat diselesaikan melalui gugtan sederhana.

Batasan nilai materil gugatan Rp. 500.000.000 (lima ratus jutarupiah) misalnya yang memberi arti jikalau gugatan yang diajukan melebih nilai tersebut, maka gugatan tidak akan diterima untuk diselesaikan melalui proses beracara gugatan sederhana. Jangka waktu proses penyelesaian perkara yang dibatasi sampai batas waktu maksimal 25 hari kerja sejak sidang pertama dijalankan, menjadikan panitera harus teliti dalam melakukan pemeriksaan berkas gugatan dan begitu juga dibutuhkan ketelitian penilaian oleh hakim baik di dalam pemeriksaan pendahuluan maupun pemeriksaan persidangan sampai memberikan putusan.

Pelaksanaan putusaan hakim yang mengedepankan prinsip sukarela para pihak memang penting dan ideal untuk diterapkan, akan tetapi perlu adanya penegasan lebih jelas dan aplikatif perihal upaya apa yang harus dilakukan oleh pihak yang

27 Wawancara dengan Bapak Julius Bolla Ketua Panitera Pengadilan Negeri Selong pada hari Rabu, tanggal 5Agustus Tahun 2020.
26 Wawancara dengan Zainul Fikri, Kuasa Hukum Penggugat Perkara Nomor Nomor 18/Pdt.G.S/2018/PN.Sel pada hari, Jumat tanggal 7 Agustus 2020 
dimenangkan manakala pelaksanaan secara sukarela itu tidak tercapai. Ketua Mahkamah Agung perlu mengeluarkan aturan khusus yang mengikat tentang pelaksanaan hasil putusan gugatan sederhana yang tidak tercantum pada Perma No. 2 Tahun 2015 dan Perma No. 4 Tahun 2019.

Penyebarluasan Perma No. 2 Tahun 2015 dan Perma No. 4 tahun 2029 kepada semua pihak, baik aparatur penegak hukum maupun masyarakat secara menyeluruh perlu ditingkatkan. Agar masyarakat luas mengetahui adanya sistem dan tata cara penyelesaian perkara-perkara yang lebih sederhana, cepat terselesaiakan, dan biaya lebih ringan daripada proses peradilan biasa terhadap permasalahan-permasalahan hukum keperdataan khususnya klasifikasi wanprestasi.

\section{DAFTAR PUSTAKA}

\section{a. Buku-buku}

Amriani, Nurnaningsih. Mediasi Alternatif Sengketa di Pengadilan. Surakarta: PT Raja Grafindo Persada. 2012.

Burhan Ashshofa, Metode Penelitian Hukum, Penerbit Rineka Cipta, 2001

Kansil, C.S.T, Pengantar IImu Hukum dan Tata Hukum Indonesia, Jakarta Balai Pustaka. 1989.

Mertokusumo, Sudikno. Hukum Acara Perdata Indonesia. Yogyakarta. Liberty, 1998.

Soerjono Soekanto. Pengantar Penelitian Hukum. Jakarta. UI-Press, 2010

Soerjono Soekanto dan Purnadi Purbacaraka, Aneka Cara Pembedaan Hukum, (Bandung: PT Citra Aditya Bakti, 1994)

Subekti. Hukum Perjanjian, Jakarta : Intermasa. 2001.
Nargis, Nila dan Marindowati. Sendi- Sendi Hukum Acara Perdata. Bandar Lampung : Justice Publiser. 2014.

Asnawi, M. Natsir, Hukum Acara Perdata Teori, Praktik dan Permasalahannya . Jakarta, 2016.

Sembiring, Jimmy Joses. Cara Penyelesaian Sengketa Di Luar Pengadilan. Jakarta : Visi Media. 2011.

Pasaribu, Chairuman. Hukum Perjanjian Dalam Islam. Jakarta Sinar Grafika. 1994.

Peter Mahmud Marzuki, Penelitian Hukum, Cet.2, (Jakarta: Kencana Prenada Media Group, 2005)

Winarta, Frans Hendra. Hukum Penyelesaian Sengketa: Arbitrase Nasional Indonesia dan Internasional. Jakarta: Sinar Grafika. 2011.

\section{b. Peraturan Perundang-undangan}

Republik Indonesia, Kitab Undang-Undang Hukum Perdata (KUHPerdata).

Republik Indonesia, Peraturan Mahkamah Agung RI Nomor 2 Tahun 2015 tentang Tata Cara Penyelesaian Gugatan Sederhana

Republik Indoesia,Peraturan Mahkamah Agung Nomor 4 Tahun 2019 tentang Perubahan Atas Peraturan Mahkamah AgungNomor 2 Tahun 2015 tentang Tata Cara Penyelesaian Gugatan Sederhana

Republik Indonesia, Undang-Undang Nomor 12 Tahun2011 tentang Pembentukan Peraturan Perundang -Undangan.

\section{c. Website}

http://www.bphn.go.id/data/documents/eksist ensi peraturan perundang-undangan. pdf (diakses pada tanggal 30 April 2020, pukul 13.25). 